\title{
Phylogeny, AdaPtive Radiation, ANd historical BIOGEOGRAPHY IN BROMELIACEAE: INSIGHTS FROM AN EIGHT-LOCUS PLASTID PHYLOGENY ${ }^{1}$
}

\author{
Thomas J. Givnish ${ }^{2,15}$, Michael H. J. Barfuss ${ }^{3}$, Benjamin Van EE ${ }^{2,4}$, Ricarda Rinna ${ }^{2,5}$, \\ Katharina Schulte ${ }^{6,7}$, Ralf Horres ${ }^{8}$, Philip A. Gonsiska ${ }^{2}$, Rachel S. Jabaily ${ }^{2,9}$, \\ Darren M. Crayn ${ }^{7}$, J. Andrew C. Smith ${ }^{10}$, Klaus Winter ${ }^{11}$, Gregory K. Brown ${ }^{12}$, \\ Timothy M. Evans ${ }^{13}$, Bruce K. Holst ${ }^{14}$, Harry Luther ${ }^{14}$, Walter Till ${ }^{3}$, \\ Georg Zizka $^{6}$, Paul E. Berry ${ }^{5}$, and Kenneth J. Sytsma ${ }^{2}$
}

\begin{abstract}
${ }^{2}$ Department of Botany, University of Wisconsin-Madison, Madison, Wisconsin 53706 USA; ${ }^{3}$ Department of Systematic and Evolutionary Botany, Faculty of Life Sciences, University of Vienna, Vienna A-1030, Austria; ${ }^{4}$ Department of Organismic and Evolutionary Biology, Harvard University, Cambridge, Massachusetts 02183 USA; ${ }^{5}$ Department of Ecology and Evolutionary Biology, University of Michigan, Ann Arbor, Michigan 48109 USA; ${ }^{\circ}$ Department of Botany and Molecular Evolution, Research Institute Senckenberg and J. W. Goethe University, Frankfurt am Main D-60325, Germany; ${ }^{7}$ Australian Tropical Herbarium, James Cook University, Cairns QLD 4878, Australia; ${ }^{8}$ GenXPro, Frankfurt am Main 60438 Germany; ${ }^{9}$ Department of Biological Sciences, Old Dominion University, Norfolk, Virginia 23529 USA; ${ }^{10}$ Department of Plant Sciences, University of Oxford, Oxford OX1 3RB, UK; ${ }^{11}$ Smithsonian Tropical Research Institute, Balboa, Ancon, Republic of Panama; ${ }^{12}$ Department of Botany, University of Wyoming, Laramie, Wyoming 82071 USA; ${ }^{13}$ Department of Biology, Grand Valley State University, Allendale, Michigan 49401 USA; and ${ }^{14}$ Marie Selby Botanical Gardens, Sarasota, Florida 34236 USA
\end{abstract}

- Premise: Bromeliaceae form a large, ecologically diverse family of angiosperms native to the New World. We use a bromeliad phylogeny based on eight plastid regions to analyze relationships within the family, test a new, eight-subfamily classification, infer the chronology of bromeliad evolution and invasion of different regions, and provide the basis for future analyses of trait evolution and rates of diversification.

- Methods: We employed maximum-parsimony, maximum-likelihood, and Bayesian approaches to analyze 9341 aligned bases for four outgroups and 90 bromeliad species representing 46 of 58 described genera. We calibrate the resulting phylogeny against time using penalized likelihood applied to a monocot-wide tree based on plastid $n d h F$ sequences and use it to analyze patterns of geographic spread using parsimony, Bayesian inference, and the program S-DIVA.

- Results: Bromeliad subfamilies are related to each other as follows: (Brocchinioideae, (Lindmanioideae, (Tillandsioideae, (Hechtioideae, (Navioideae, (Pitcairnioideae, (Puyoideae, Bromelioideae))))))). Bromeliads arose in the Guayana Shield ca. 100 million years ago (Ma), spread centrifugally in the New World beginning ca. 16-13 Ma, and dispersed to West Africa ca. 9.3 Ma. Modern lineages began to diverge from each other roughly $19 \mathrm{Ma}$.

- Conclusions: Nearly two-thirds of extant bromeliads belong to two large radiations: the core tillandsioids, originating in the Andes ca. 14.2 Ma, and the Brazilian Shield bromelioids, originating in the Serro do Mar and adjacent regions ca. 9.1 Ma.

Key words: Andes; Bromeliaceae; bromeliads; epiphytes; Guayana Shield; historical biogeography; neotropics; Poales; Serra do Mar; tank formation.

\begin{abstract}
${ }^{1}$ Manuscript received 13 February 2010; revision accepted 9 February 2011.

The authors gratefully acknowledge financial support for this investigation by grants from the National Science Foundation to P.E.B., K.J.S., and T.J.G. (DEB-9981587), T.J.G. (DEB-0830036), K.J.S. (DEB0431258), and G.L.B. and T.M.E. (DEB-0129446 and DEB-0129414), and from the Hertel Gift Fund to T.J.G., from the Commission for Interdisciplinary Ecological Studies (KIÖS) at the Austrian Academy of Sciences (ÖAW, 2007-02 to W.T. and M.H.J.B., and from the Deutsche Forschungsgemeinshaft (ZI 557/7-1, SCHU 2426/1-1) and the Hessian initiative for the development of scientific and economic excellence (LOEWE) at the Biodiversity and Climate Research Centre, Frankfurt am Mein, to G.Z. and K.S. Plant material was kindly supplied by the Selby Botanical Garden, the Palmengarten Frankfurt am Main, and the Botanical Gardens of Heidelberg. Alejandra Gandalfo provided some useful references on the geological history of the Andes. Many thanks to two anonymous reviewers and D. E. Soltis for several helpful suggestions.

${ }^{15}$ Author for correspondence (e-mail: givnish@ wisc.edu)
\end{abstract}

doi:10.3732/ajb.1000059
The family Bromeliaceae (58 genera, ca. 3140 species) constitute one of the most morphologically distinctive, ecologically diverse, and species-rich clades of flowering plants native to the tropics and subtropics of the New World (Fig. 1). Bromeliads range from mist-shrouded tepuis in Venezuela to sun-baked granitic outcrops of the Brazilian Shield, from cloud forests in Central and South America to the cypress swamps of the southern United States, and from the frigid Andean puna to the arid Atacama (Smith and Downs, 1974; Givnish et al., 1997; Benzing 2000). Their distinctive leaf rosettes often impound rainwater in central tanks, possess the CAM photosynthetic pathway, and bear absorptive trichomes, providing mechanisms to weather drought and obtain or conserve nutrients on rocks and exposed epiphytic perches (Pittendrigh, 1948; McWilliams, 1974; Crayn et al., 2004; Givnish et al., 2007; Schulte et al., 2009). Bromeliad tanks also house a great diversity of insects-including some with substantial impact on human health - and other arthropods, as well as crabs, frogs, salamanders, and snakes. 
In a hectare of cloud forest, these tanks can sequester tens of thousands of liters of rainwater and trap hundreds of kilograms of humus high in the canopy and provide key food sources for many primates and birds (Paoletti et al., 1991; Leme, 1993; Sillett, 1994; Richardson, 1999; Benzing, 2000; Acevedo et al., 2008). Some tank bromeliads are directly carnivorous (Fish, 1976; Frank and O’Meara, 1984; Givnish et al., 1984, 1997), and at least one is known to benefit from the prey captured by inquiline spiders (Romero et al., 2006). Many tank bromeliads are protected and/or fed by ants (Benzing, 1970, 2000; McWilliams, 1974; Givnish et al., 1997). Pollinators include a wide variety of insects, as well as hummingbirds, bats, and a few perching birds (Benzing, 1980, 2000; Luther, 1993; Beaman and Judd, 1996; Smith and Till, 1998; Buzato et al., 2000; Krömer et al., 2006; Tschapka and von Helversen, 2007). The inflorescences of Puya raimondii are the most massive of any flowering plant, while those of some dwarf Brocchinia and Tillandsia are only a few centimeters in height (Fig. 1). Finally, bromeliads contribute a large share of the total species richness of vascular epiphytes in neotropical forests, are particularly diverse at midelevations, and exhibit increasingly narrow endemism at higher elevations (Kessler, 2001; Krömer et al., 2005; Linares-Palomino et al., 2009; Linares-Palomino and Kessler, 2009).

To understand the genesis of these patterns-and, more generally, the history of adaptive radiation and geographic diversification in bromeliads-we need a well-resolved, strongly supported phylogeny for this remarkable family. Progress toward this goal initially was slow, partly because bromeliads are taxonomically isolated, with no clear outgroup with which to polarize character-states (Gilmartin and Brown, 1987; Terry et al., 1997; Givnish et al., 2000; Pires and Sytsma, 2002); partly because bromeliad plastid DNA evolves at an unusually slow rate (Gaut et al., 1992, 1997; Givnish et al., 2004, 2005); and partly because previous studies had limited taxon sampling.

Over the last dozen years, however, these roadblocks have been mostly overcome, through a greater understanding of relationships among monocot families overall (Givnish et al., 2005; Chase et al., 2006; Graham et al., 2006) and, within Bromeliaceae, through the sequencing and analysis of one or a few rapidly evolving genes and gene spacers in the plastid genome by individual laboratories (e.g., Terry et al., 1997; Horres et al., 2000; Crayn et al., 2004; Givnish et al., 2004, 2007; Sass and Specht, 2010). Based on a thorough sampling of taxa in all three traditional subfamilies - especially the critical Pitcairnioideae (characterized by winged or unappendaged seeds) — Givnish et al. (2007) presented the most comprehensive view of bromeliad phylogeny and evolution to date, based on cladistic analyses of sequences of the plastid gene $n d h F$ and calibration of the resulting molecular tree against the known ages of several monocot fossils. Their findings placed Brocchinia, then Lindmania at the base of the bromeliad family tree, sister to all other taxa. The upper branches of that tree consisted of a trichotomy including Hechtia, the subfamily Tillandsioideae (characterized by plumose seeds), and a "ladder" consisting of four clades embracing all other bromeliads, including Puya (part of the traditional Pitcairnioideae) as sister to Bromelioideae (characterized by fleshy fruits) (Fig. 2). Using this phylogeny, Givnish et al. (2007) erected a new, eight-subfamily classification for bromeliads, splitting the traditional but highly paraphyletic Pitcairnioideae into Brocchinioideae, Lindmanioideae, Hechtioideae, Navioideae, Pitcairnioideae s.s., and Puyoideae (Fig. 2). The $n d h F$ phylogeny resolved more of the higher-level relationships in Bromeliaceae than studies including fewer genera based on $n d h F$ (Terry et al.,
1997), the $t r n L$ intron (Horres et al., 2000), or matK and rps 16 (Crayn et al., 2004), but was otherwise consistent with the results of those investigations. It also provided several new insights into the historical biogeography and adaptive radiation of bromeliads. However, the $n d h F$ phylogeny provided only weak support for several nodes, failed to resolve the branching sequence of Tillandsioideae and Hechtioideae, and had a limited density of taxon sampling, including only 26 of 58 currently recognized genera, and none of the critical Chilean species of Puya (Jabaily and Sytsma, 2010) or Bromelioideae (Schulte et al., 2009).

To overcome these weaknesses, provide the basis for a more rigorous analysis of bromeliad evolution, and tap the wealth of data already in hand for several plastid loci-including those used to construct emerging, multilocus phylogenies for Bromelioideae (Schulte et al., 2005, 2009; Horres et al., 2007; Schulte and Zizka, 2008; Sass and Specht, 2010) and Tillandsioideae (Barfuss et al., 2005)—we formed an international consortium to produce a well-resolved, strongly supported phylogeny for Bromeliaceae based on multiple plastid loci and as comprehensive a sampling of bromeliad genera as could be managed.

Here we present the first results of that collaboration. To reconstruct relationships across Bromeliaceae, we completed the sequencing of eight rapidly evolving plastid regions for representatives of 46 of 58 bromeliad genera. We then used the resulting phylogeny to (1) analyze relationships within the family and test the new eight-subfamily classification, (2) infer the timing of divergence of various clades and relate these dates to events in Earth history, and (3) determine the geographical origins of the family and patterns of subsequent spread outside this region by members of each subfamily. A companion paper will calculate the rate of net species diversification for each major bromeliad clade and relate the observed differences in diversification rate to differences among clades in morphology, ecology, geographic disribution, mode of seed dispersal, and time of adaptive radiation.

\section{MATERIALS AND METHODS}

DNA extraction, taxon sampling, and selection of molecular markersTotal genomic DNAs were extracted using the protocols of Crayn et al. (2004), Barfuss et al. (2005), Schulte et al. (2005), and Givnish et al. (2007). We sequenced eight rapidly evolving plastid regions (atpB-rbcL, matK, ndhF, psbA-trnH, rpl32-trnL, $r p s 16$, trnL intron, $t r n L-t r n F)$ for 90 bromeliad species representing 46 genera, and three outgroups from Rapateaceae and Typhaceae (Appendix 1). An 81-gene analysis of relationships among monocot families (Givnish et al., 2010) placed Bromeliaceae sister to all other families of the order Poales, with Typhaceae being sister to to all families of Poales except itself and Bromeliaceae, and Rapateaceae being sister to the remaining families of Poales. We used Phoenix dactylifera (Arecaceae) as the ultimate outgroup and downloaded sequences for all eight plastid regions for this species from the complete plastome sequence posted on GenBank.

Multiple species of Aechmea, Mezobromelia, Navia, Ochagavia, Tillandsia, and Vriesea were sampled due to concerns about the monophyly of those genera (Crayn et al., 2004; Barfuss et al., 2005; Schulte et al., 2005; Sass and Specht, 2010). Multiple species of Brocchinia, Guzmania, Hechtia, Pitcairnia, and Puya were included to help resolve the critical taxonomic positions of those genera. We included representatives of all genera of Brocchinioideae, Lindmanioideae, Tillandsioideae, Hechtioideae, Pitcairnioideae, and Puyoideae, all but one genus (Steyerbromelia) of Navioideae, and all but 11 of 34 genera of Bromelioideae (including 33 listed by Butcher 2008 and Luther 2008, and retaining Pseudananas). Of the 11 genera omitted, seven (Androlepis, Fernseea, Hohenbergiopsis, Neoglaziovia, Orthophytum, Portea, Ursulaea) were included in recent multilocus studies of relationships within Bromelioideae, and all were placed in that subfamily by plastid and nuclear data (Schulte and Zizka, 2008; Schulte et al., 2009; Sass and Specht, 2010). Genera not represented in this study include less than $2.5 \%$ of all described bromeliad species (see Luther, 2008). Subfamilial nomenclature follows Givnish et al. (2007). 


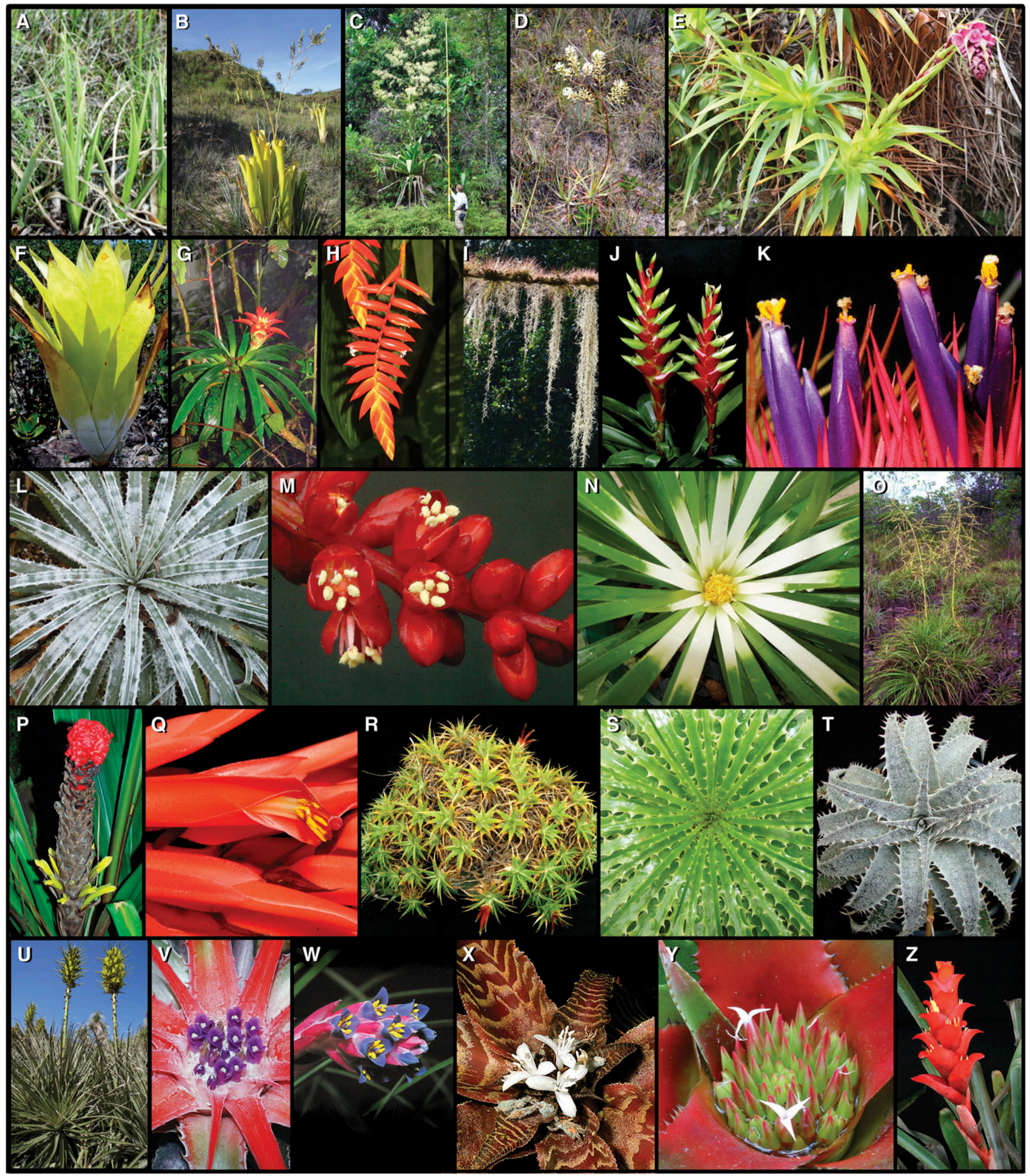

Fig. 1. Representative species of bromeliad subfamilies; images are at different scales. BROCCHINIOIDEAE: (A) Brocchinia prismatica, nonimpounding species sister to all Brocchinia, found in wet, sandy savannas in SW Venezuela; (B) B. reducta, terrestrial carnivore of damp, sandy savannas in SE Venezuela and SW Guyana; (C) tree-like B. micrantha, SE Venezuela and SW Guyana. LINDMANIOIDEAE: (D) Lindmania guianensis, SE Venezuela and SW Guyana; (E) Connellia augustae, sandstone outcrops, Venezuela and Guyana. TILLANDSIOIDEAE: (F) Catopsis berteroniana, carnivorous epiphyte, Florida to Brazil; (G) Guzmania lingulata, epiphyte, Central and N South America; (H) Tillandsia dyeriana, epiphyte, Ecuador; (I) Tillandsia setacea (above branch) and T. usneoides (Spanish moss, below branch), widespread atmospheric epiphytes; (J) Vriesea heliconioides, epiphyte, Mexico to 


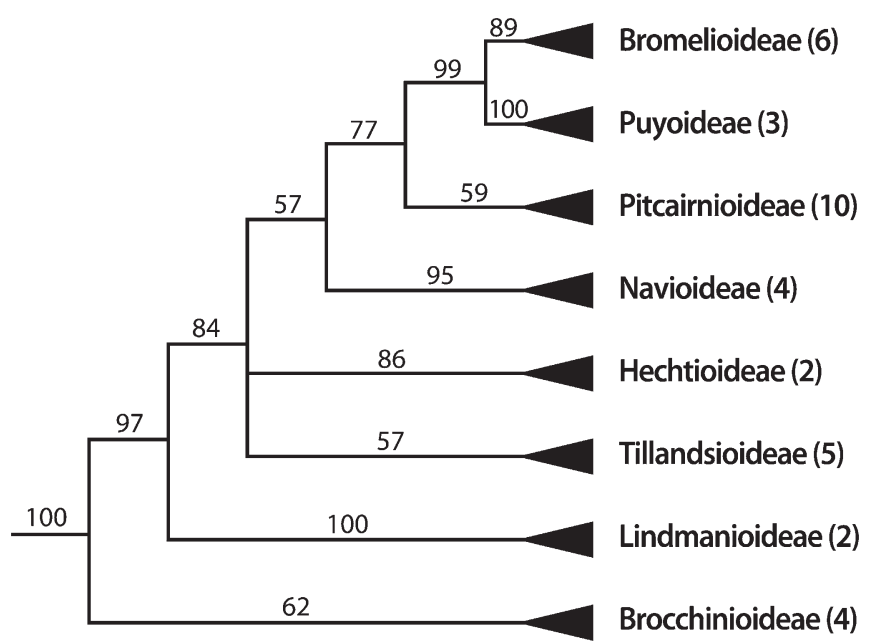

Fig. 2. Maximum-parsimony strict consensus tree from Givnish et al. (2007) based on variation in plastid $n d h F$ sequences, with proposed relationships among bromeliad subfamilies. Outgroups from seven families of order Poales not shown. Numbers above branches are bootstrap support values; numbers in parentheses after subfamilial names indicate the number of taxa included in the earlier analysis.

We believe that our approach to higher-level bromeliad phylogenetics, based solely on sequences from the plastid genome, is justified because very few natural cases of hybridization among bromeliads are known, based on morphology or on more decisive comparisons of organellar vs. nuclear DNA markers (Wendt et al., 2008; Gonçalves and de Azevêdo-Gonçalves, 2009). Partly this may be because nuclear ribosomal ITS - the nuclear locus used to screen for hybridization and/or introgression in many angiosperm lineages - has only rarely been amplified and sequenced in bromeliads, given its strong hairpin geometry in this group (T. M. Evans, personal communication). However, Schulte et al. (2009), Gonsiska (2010), Jabaily and Sytsma (2010), and Sass and Specht (2010), employing other nuclear markers (PhyC, $P R K$, and nrDNA ETS) with plastid sequences to evaluate relationships among hundreds of species, have identified only a very small number of putative hybrids, most notably the ancestor of the Chilean clade of Puya and one species of Catopsis. Thus, here we rely on multiple loci from the plastome genome to reconstruct evolutionary relationships, recognizing that the validity of our plastid phylogeny should be tested when it becomes possible to sequence and align low-copy nuclear genes across all subfamilies.

DNA amplification, sequencing, and alignment-Methods for amplifying and cycle-sequencing different plastid regions from total DNA extracts followed Barfuss et al. (2005) for atpB-rbcL and rps16; Crayn et al. (2004) for $m a t K$; Givnish et al. (2007) for $n d h F$; Horres et al. $(2000,2007)$ for the $\operatorname{trn} L$ intron and trnL-trnF; and Shaw et al. (2007) for psbA-trnH and rpl32-trnL. Sequences were visually aligned following Baum et al. (1994). Stretches of DNA that were difficult to align (i.e., there were multiple conflicting alignments possible under the assumptions of Baum et al.) or had missing data for a substantial number of taxa were excluded from analysis. We were unable to complete $60(9.2 \%)$ of 651 sequences. GenBank accession numbers were acquired for all new sequences; previously obtained sequences were downloaded from GenBank (Appendix 1). An aligned data set has been deposited in
TreeBase (http://www.treebase.org/treebase-web/home.html; accessed 04-07-11), together with the maximum likelihood and Bayesian trees as case S11152.

Phylogenetic analyses-We inferred relationships from the nucleotide data using maximum parsimony (MP), maximum likelihood (ML), and Bayesian inference (BI). MP analyses were conducted using the program PAUPRat (Sikes and Lewis, 2001), based on Parsimony Ratchet (Nixon, 1999) and implemented in the Cyberinfrastructure for Phylogenetic Research (CIPRES) portal 2 teragrid (http://www.phylo.org) (Miller et al., 2010). Individual bases were considered multistate, unordered characters of equal weight; unknown nucleotides were treated as uncertainties. Following Nixon (1999) and Goloboff (1999), we performed multiple (50) independent searches in PAUPRat to cover tree space adequately. Each search involved 500 iterations, with the shortest trees from each search used to form a strict consensus tree and a majority-rule tree. Shortest trees from each successive search were combined with previous search trees to evaluate whether the combined search consensus tree had stabilized. Stabilization of a consensus tree based on multiple, independent searches in PAUPRat supports the accuracy of the topology obtained (Goloboff, 1999). We used bootstrap analysis (Felsenstein, 1985) in the program PAUP* 4.0b10 (Swofford, 2002) to assess the relative support for each node in the strict consensus, using 1000 random resamplings of the data and retaining 200 trees per iteration. To determine the extent to which the lower support for the monophyly of Puyoideae and Bromelioideae in this study vs. Givnish et al. (2007) was due to our inclusion here of a number of Chilean Puya and Chilean bromelioids and Deinacanthon of the nearby Gran Chaco, respectively, we removed the latter from the analysis and recalculated support values for Puyoideae and Bromelioideae. Consistency indices, including autapomorphies $(\mathrm{CI})$ and excluding them $\left(\mathrm{CI}^{\prime}\right)$, were calculated to evaluate the extent of homoplasy in the data (Givnish and Sytsma, 1997). Maximum-parsimony phylogenies were also formed for each plastid region, and incongruence length difference (ILD) tests (Farris et al., 1994) were conducted for each pair of regions $(n d h F, m a t K, \operatorname{trnL}-\operatorname{trnF}, a t p B-r b c L, p s b A-t r n H, r p l 16$, rpl32-trnL) in PAUP* after removing taxa not sequenced for either region, to assess potential conflicts between regions in phylogenetic structure.

Maximum-likelihood analyses used the program jModelTest 0.1.1 (Posada, 2008) based on the program Phyml (Guindon and Gascuel, 2003) to select the appropriate model of nucleotide evolution using the Akaike information criterion (AIC) (Posada and Buckley, 2004). We evaluated models for each of the plastid regions separately and the entire concatenated sequence. The most likely tree was produced using the program GARLI (Genetic Algorithm for Rapid Likelihood Inference; Zwickl, 2006) in CIPRES. Multiple models for each gene partition are not allowed in GARLI, so the more complex model for a given set of genes was chosen. Maximumlikelihood bootstrapping (MLB) was completed using the program RAxML 7.0.4 (Stamatakis et al., 2005, 2008).

Bayesian inference was performed in the program MrBayes 3.1 (Ronquist and Huelsenbeck, 2003) allowing different models for each region. Four independent runs of 5000000 generations each were completed with a chain temp of 0.2 . Trees were sampled every 1000 generations. The first $25 \%$ of runs were discarded as burn-in. A majority rule consensus of the remaining trees from the four runs was produced in PAUP* 4.0 and used as the Bayesian inference tree with posterior probabilities (PP). We also explored the mixture model of Pagel and Meade (2008) as implemented in the program BayesPhylogenies (Pagel and Meade, 2004). This model allows the fit of more than one model of evolution to each site in the alignment. We used the recommended GTR $+\Gamma$ model with "patterns $=2$, pi=true", allowing two rate matrices to be formed and allowing both rate parameters and base frequencies to vary.

Dating radiations - An indirect approach to calibrating the bromeliad phylogeny is required because almost all bromeliads occur in habitats that are poor

Bolivia; (K) Tillandsia ionantha, flowers of tiny atmospheric epiphyte, Central America. HECHTIODEAE: (L) Hechtia mooreana, CAM terrestrial, Mexico; (M) partial inflorescence, H. rosea, CAM terrestrial, Mexico. NAVIOIDEAE: (N) Navia aff. lactea, saxicole, S Venezuela; (O) Sequencia serrata, E Colombia. PITCAIRNIOIDEAE: (P) Pitcairnia holstii, low-elevation terrestrial, Venezuela; (Q) bird-pollinated flowers, P. undulata, Mexico; (R) Deuterocohnia lotteae, high-elevation Andean cushion plant, S Bolivia; (S) Encholirium spectabile, CAM terrestrial, NE Brazil; (T) Dyckia lindevaldae, CAM terrestrial, Brazil. PUYOIDEAE: (U) Puya chilensis, tall terrestrial, Chile, cultivated at the Huntingdon Botanical Garden. BROMELIOIDEAE: (V) Bromelia macedoi, CAM terrestrial, Brazil; (W) Fernseea bocainensis, SE Brazil; (X) Cryptanthus fosterianus, nonimpounding CAM terrestrial, SE Brazil; (Y) Neoregelia eleutheropetala var. bicolor, CAM epiphyte with flowers emerging from tank, S tropical America; and (Z) Canistrum alagoanum, CAM epiphyte with flowers emerging from tank, SE Brazil. Photo credits: A, Thomas Givnish; B, Peggy Faucher; O, Julio Betancour; T, Reginaldo Baião; all others, Bruce Holst. 
for fossil preservation. There is only one macrofossil clearly assignable to Bromeliaceae, from Costa Rica 36 million years ago (Ma) (Smith and Till, 1998), long after both existing estimates of the age of origin of Bromeliaceae based on molecular data (Givnish et al., 2004, 2007). Lemé et al. (2005) recently erected a new family for a bromeliad-like fossil (Protananas lucenae) from northeastern Brazil in limestone 100-110 Myr old. The authors report, however, that this taxon appears to be a nonbromeliad close to the base of order Poales.

We conducted two analyses to assess the timing of the rise of the bromeliad stem lineage within Poales and of the crown radiation of the family. First, building on previous monocot-wide analyses of relationships and fossil dating (Bremer, 2000; Givnish et al., 2000, 2005; Janssen and Bremer, 2004), we used $n d h F$ sequences of 333 taxa of monocots (including 71 from Bromeliaceae) and the outgroup Ceratophyllum to build a monocot-wide phylogeny. The ML tree derived in GARLI using a model from jModelTest was used for subsequen fossil calibration. As $n d h F$ alone does not have the power to resolve several key nodes, we constrained five areas of the monocot backbone based largely on the results of a recent monocot-wide study employing 81 plastid genes (Givnish et al., 2010). These constraints included (1) (Araceae, (Tofieldiaceae, all other Alismatales)); (2) (Liliales, (Asparagales + commelinids)); (3) (Dasypogonaceae, Arecaceae); (4) (Poales, (Commelinales, Zingiberales)); and (5) (Bromeliaceae, (Typhaceae, (Rapateaceae, all other Poales))). We used the Langley and Fitch (1974) method, as implemented in the program r8s (Sanderson 2004), to reconstruct divergence times on the ML tree with Ceratophyllum pruned off assuming a molecular clock and conduct a $\chi^{2}$ test of rate constancy to test for significant deviation from clocklike evolution. Given the nonclocklike pattern of evolution observed, we converted the ML tree into ultrametric form using penalized likelihood (PL) in r8s (Sanderson, 2002, 2004), calibrated agains monocot-wide fossils.

Six Cretaceous fossils were used to constrain the corresponding nodes as minimum ages (Janssen and Bremer, 2004; Givnish et al., 2005; Hesse and Zetter, 2007). The monocot root was fixed at $134 \mathrm{Ma}$ (Bremer, 2000; Janssen and Bremer, 2004). Penalized likelihood smoothes local differences in the rate of DNA evolution on different branches, taking into account branch lengths and branching topology and assigning a penalty for rate changes among branches that are too rapid or frequent, based on a smoothness parameter. We used the cross-verification algorithm in r8s (Sanderson, 2004) to find the optimal value of the smoothness parameter, based initially on minimizing the sum of the squared deviations between the observed and expected branch lengths derived by jackknifing each branch (Sanderson, 2002). We varied the smoothness parameter from $10^{\circ}$ to $10^{3}$ in steps of 0.25 of the exponent. The optimal value of the smoothness parameter was validated using the check-gradient algorithm in r8s. We ran separate r8s analyses using a range of smoothness values near the optimum to examine the impact of different values on variation in the stem and crown age of Bromeliaceae and chose the final value of the smoothing parameter based on minimization of that variation within the window of values that yield similar, near-minimal sums of the squared deviations between observed and expected branch lengths (see above). To estimate uncertainties in node age due to uncertainties in the monocot-wide $n d h F$ branching topology, we calculated the standard deviation of the estimated age for each node (including those within Bromeliaceae) by forming 100 bootstrap resamplings of the sequence data employing the program PHYLIP (Felsenstein, 1993) and then using these to calculate realized branch lengths of the original ML tree for each resampling. The optimal smoothness parameter obtained for the entire data set was used in calculations for each resampling.

Second, we conducted a detailed r8s analysis of the entire eight-locus Bromeliaceae data set (including $n d h F$ ) with Rapatea (Rapateaceae) and Typha and Sparganium (Typhaceae), as well as the ultimate outgroup Phoenix (Arecaceae). Although the monocot-wide $n d h F$ phylogenetic and fossil-dating analyses included Bromeliaceae, the eight-locus data set is essential for obtaining a more finely resolved estimate of branching events and their timing within the family. The stem and crown dates of Bromeliaceae obtained from the fossilcalibrated $n d h F$ monocot chronogram were used as fixed dates in r8s for the eight-locus ML tree after removing Phoenix. Due to the ambiguity of monophyly in Puya based on plastid data, but the compelling support for it from nuclear sequence data and morphology (Jabaily and Sytsma, 2010), we ran r8s analyses with Puya constrained to be monophyletic.

To estimate variation in node age due to uncertainties in the derived node dates of the eight-locus data set and in the $n d h F$ stem and crown node dates, we performed three further analyses. First, we calculated the standard deviation of inferred age at each node via 100 bootstrap resamplings of the eight-locus data set. Second, we calculated the standard deviation of both the stem and crown nodal dates for Bromeliaceae based on 100 bootstrap resamplings of the monocot-wide $n d h F$ data; this allowed us to generate of the mean \pm SD of the inferred ages for both the stem and crown nodes based directly on fossil calibration. Given that variation in inferred node ages is a function of random variation in the ages of the set-dates independent of random variation in node ages due to uncertainty in the eight-locus phylogeny, an estimate of the total standard deviation of inferred age at the stem and crown nodes can be estimated as $\mathrm{SD}_{\text {total }}=$ $\left(\mathrm{SD}^{2} \text { set-dates }+\mathrm{SD}_{\text {phyl uncertainty }}\right)^{0.5}$ (see Givnish et al., 2009). Finally, to quantify any bias or degree of uncertainty resulting from using the stem and crown ages from the $n d h F$ tree to calibrate the eight-locus tree, we regressed the stem and crown ages for several critical nodes (each subfamily; the core tillandsioids, Navia/Brewcaria, Pitcairnia, and the Brazilian Shield and epiphytic tank bromelioid clades [see Results]; Puyoideae + Bromelioideae; and Puyoideae + Bromelioideae + Pitcairnioideae) for the eight-locus tree on those for the $n d h F$ tree, eliminating the stem age of Bromelioideae to avoid duplication.

We related the timing of inferred cladogenetic events to the times of uplift and dissection of the tepuis of the Guayana Shield, formation of the Amazon basin, uplift of the Andes and Brazil's Serra do Mar, and shifts in regional climate as estimated by a variety of geological, climatological, and biogeographic studies (e.g., Vasconcelos et al., 1992; Hoorn et al., 1995, 2010; van der Hammen, 1995; Amorim and Pires, 1996; Potter, 1997; Safford, 1999; Coltorti and Ollier, 2000; Gregory-Wodzicki, 2000; Auler and Smart, 2001; Behling and Negrelle, 2001; Wang et al., 2004; Grazziotin et al., 2006; Garzione et al., 2008; Antonelli et al., 2009; Ehlers and Poulsen, 2009; Figueiredo et al., 2009). Special attention was paid to the stem and crown ages of each subfamily, the core tillandsoids (sister to Catopsis and Glomeropitcairnia), and the clade of tank species sister to Acanthostachys (the core bromeliads; see Schulte et al., 2009).

Historical biogeography - To reconstruct spatial patterns of geographic diversification within Bromeliaceae, we employed three contrasting methods and accompanying assumptions implemented in the programs Statistical DispersalVicariance Analysis (S-DIVA; Yu et al., 2010), BayesTraits (Pagel and Meade, 2007), and MacClade 4.08 (Maddison and Maddison, 2005). Given that the stem lineage of the family is already known to extend back to the Cretaceous but with a far more recent crown radiation (Givnish et al., 2004, 2007), and that bromeliads are clearly capable of long-distance dispersal-for example, from South America to the Galápagos (Racinaea insularis, Tillandsioideae), the Juan Fernandez Islands (Greigia berteroi and Ochagavia elegans, Bromelioideae), and tropical West Africa (Pitcairnia feliciana, Pitcairnioideae); see Smith and Downs (1974, 1977, 1979) and Givnish et al. (2007)—any assumption about the relative importance of vicariance vs. dispersal in Bromeliaceae would be difficult to justify. Programs to evaluate geographic diversification either favor vicariance (e.g., dispersal-vicariance analysis [DIVA, Ronquist, 1996, 1997; and S-DIVA]) or allow any amount of dispersal between areas (e.g., BayesTraits or MacClade using BI and MP criteria, respectively). Explicit, modeldriven analyses of geographic diversification are possible (Ree et al., 2005; Ree and Smith, 2008), especially in the context of well-known geological events (e.g., continental vicariance as in Clayton et al., 2009), but remain premature for examining diversification within and among areas of geologically complex South America.

To minimize some of the shortcomings inherent in DIVA (Nylander et al., 2008; Harris and Xiang, 2009; Kodandaramaiah, 2010), we instead used SDIVA (Yu et al., 2010). DIVA optimizes distributions for each node by allowing vicariance but minimizing assumptions of dispersal and extinction. S-DIVA extends DIVA by permitting assessment of phylogenetic uncertainty by examining multiple trees (in our case, a random subset of post burn-in Bayesian trees), each of which may contain polytomies.

Ranges of terminal taxa were atomized into recognized areas of endemism largely following Givnish et al. (2007) and (except for fusion of all Andean regions) Antonelli et al. (2009), including (1) Guayana Shield; (2) Brazilian Shield (including the Serra do Mar and Serra da Mantiqueira, as well as the adjacent Phanerozoic deposits of the Horn of Brazil and the Rio de la Plata basin); (3) Amazonia; (4) Caribbean (including the coast of northern South America and the southeastern United States); (5) Central America (including semiarid southern Texas); and (6) tropical West Africa. Distributional data were drawn from Smith and Downs (1974, 1977, 1979). Following the recommendation of Ronquist (1996), terminal species representing higher taxa (i.e., genera) were scored for ancestral area where possible (specifically, for Catopsis in Central America [Gonsiska, 2010]). When that approach was not justified or feasible, we scored single placeholders for all portions of the generic range (e.g., Bromelia) despite the known sacrifice in geographical resolution at deeper nodes in S-DIVA reconstructions (Ronquist, 1996). Multiple species per genus were each scored based on their own distribution. Vicariance between the Guayana Shield and the Andes, Caribbean, and Central America were excluded, as was 
vicariance between tropical West Africa and any other region, due to the lack of any geographic contact between these regions over the inferred age of the bromeliad stem group. Due to the ancient split of Bromeliaceae from all other Poales, we performed several iterations of S-DIVA with respect to different outgroups (i.e., Rapateaceae and Typhaceae). Rapateaceae (and other lineages among the early splits in Poales) are Guayanan, whereas Typhaceae are cosmopolitan. We thus ran S-DIVA with the two outgroup families scored as Guayana Shield and polymorphic, respectively. We also ran analyses after scored both outgroups as Guayana Shield, due to the strong signal of Guayana Shield as basal in more Poales-wide biogeographic analyses (Givnish et al., 2000, 2004 2007). Last, we removed Typhaceae entirely as an outgroup, as advocated by Bremer (2002), who removed this aquatic, easily dispersed group in DIVA analysis because it would be dangerous to base any conclusions regarding ancestral distributions on their present distributions. A random subset of 1000 Bayesian posterior probability trees from the phylogenetic analysis of the eightlocus data set were input into S-DIVA to estimate probabilities of ancestral areas at each node. We explored the impact of restricting the number of unit areas allowed in ancestral distributions by using the maxareas option (all possible areas, 4, and 2). The ancestral areas for all nodes were visualized on the ML tree with Puya constrained to be monophyletic.

We also analyzed the biogeographical data using ML and MP reconstructions that relax emphasis on vicariance by permitting dispersal between any pair of biogeographic areas. We implemented BI optimization of ancestral areas (Pagel, 1999) with the Markov chain Monte Carlo (MCMC)-based BayesMultiState option in the program BayesTraits v.1.0 (Pagel and Meade, 2007) using the ML tree with Puya constrained to be monophyletic to portray ancestral area reconstructions. To reduce some of the uncertainty and arbitrariness of choosing priors under MCMC, we used the hyperprior approach (the rjhp command) as recommended (Pagel et al., 2004; Pagel and Meade 2007). Combinations of hyperprior values (exponential or gamma, mean and variance) and rate parameter values were explored to find acceptance rates when running the Markov chains of between 20 and $40 \%$ (as recommended by Pagel and Meade, 2007). All subsequent analyses used the reversible-jump hyperprior command (rjhp gamma 030010 ) that seeded the mean and variance of the gamma prior from uniform hyperpriors on the interval 0 to 30 and 0 to 10, respectively, and a rate parameter of 150 (ratedev 150). We reconstructed ancestral areas using MP by overlaying the ranges of individual species (or inferred ancestral area for Catopsis) using MacClade 4.08 (Maddison and Maddison, 2005), resolving all of the most parsimonious states at each node of the ML tree.

\section{RESULTS}

Phylogeny - We obtained an aligned data matrix of 94 taxa $\times$ 9341 characters; of the latter, 1210 were parsimony-informative and 1429 were variable but parsimony-uninformative (Table 1). The number of informative characters varied nearly 6-fold among loci, from 61 for $p s b A$-trnH to 357 for $n d h F$. The fraction of informative sites varied from $8.8 \%$ ( $p s b A-t r n H)$ to $16.2 \%$ (rpl32-trnL). The numbers of informative vs. variable but uninformative characters were strongly correlated with each other across loci ( $r=0.97, P<0.0001$ for two-tailed $t$ test with $6 \mathrm{df}$ ), and the ratio of informative to variable but uninformative characters averaged $0.85 \pm 0.074$ (mean \pm SD). Within Bromeliaceae, 1663 characters were variable, of which 766 were informative.
Maximum parsimony resulted in a single island of 1317600 trees of length 4546 steps, and a strict consensus tree that was well resolved outside subfamily Bromelioideae (Fig. 3). The consistency index CI for these trees was 0.70; CI' (excluding autapomorphies) was 0.54 . Branches that were unusually short (see below) were usually lost in the strict consensus tree relative to the majority-rule tree (Fig. 3).

The MP strict consensus tree supported the monophyly of all eight proposed subfamilies; each had 99-100\% bootstrap support except Puyoideae and Bromelioideae (Fig. 3). Chilean Puya formed a clade with $100 \%$ bootstrap support; non-Chilean Puya had $99 \%$ support. Puya as whole-while resolved as monophyletic-had less than 50\% support (Fig. 3). Bromelioideae had $59 \%$ bootstrap support. Bromelia, FasciculariaOchagavia, Deinacanthon, and Greigia formed a weakly supported clade sister to all other bromelioids in the MP majorityrule tree and a basal polytomy in the strict consensus tree. Pseudananas is sister to the remaining bromelioids (61\% bootstrap), then Ananas. A core group of bromelioids, sister to and including Ananas, had $88 \%$ bootstrap support, but seven of 24 relationships within this core group were unresolved in the strict consensus (Fig. 3). The clade consisting of Bromelioideae and Puyoideae had 100\% bootstrap support.

Support levels for the monophyly of each of the eight subfamilies in the strict consensus tree were generally much higher than those in the original $n d h F$ phylogeny (Figs. 2, 3), except for Puyoideae and Bromelioideae. Experimental removal of taxa show that these two subfamilies had lower support in the curent analysis due to our inclusion of Chilean Puya, Chilean bromelioids, and Deinacanthon from the nearby Gran Chaco. Relationships among the eight subfamilies agreed with those in the original $n d h F$ phylogeny (Fig. 2) but were better supported. In addition, the eight-locus data set resolved the subfamilial trichotomy present in the $n d h F$ phylogeny, placing Hechtioideae sister to (Navioideae, (Pitcairnioideae, (Bromelioideae, Puyoideae))), and Tillandsioideae sister to all five subfamilies (Fig. 3).

In both the strict consensus and majority-rule trees, Brocchinia, Guzmania, Hechtia, Deuterocohnia, Dyckia, Encholirium, Fosterella, Pitcairnia, Puya, Ananas, and Araeococcus emerged as monophyletic. In contrast, Lindmania, Tillandsia, Navia, and Ochogavia were paraphyletic; Mezobromelia, Vriesea, and especially Aechmea (with at least six apparent "origins") were polyphyletic (Fig. 3). In the MP majority-rule tree, Acanthostachys was sister to taxa corresponding to the tank-bromelioid clade ("core bromelioids") of Schulte et al. (2009) and its sister Cryptanthus; Acantostachys, Cryptanthus, and the tank bromelioids formed an unresolved trichotomy in the strict consensus (Fig. 3).

MP trees based on individual plastid regions were less resolved and less well supported than the strict consensus phylogeny

TABLE 1. Numbers of parsimony-informative, variable but parsimony-uniformative, and invariant sites for each of the plastid regions sequenced, as well as the consistency indices (with and without autapomorphies) and proportion of informative sites for those regions.

\begin{tabular}{|c|c|c|c|c|c|c|c|c|}
\hline Region: & matK & $n d h F$ & rps16 & $a t p B-r b c L$ & psbA trnH & rpl32-trnL & trnL-trnF, trnL intron & Total \\
\hline No. informative sites & 213 & 247 & 132 & 123 & 70 & 195 & 169 & 1149 \\
\hline No. variable but uninformative sites & 200 & 310 & 151 & 145 & 71 & 251 & 170 & 1298 \\
\hline No. invariant sites & 1218 & 1541 & 862 & 1109 & 759 & 937 & 808 & 7234 \\
\hline Consistency index $(\mathrm{CI})$ & 0.70 & 0.71 & 0.72 & 0.66 & 0.69 & 0.72 & 0.73 & 0.71 \\
\hline $\mathrm{C}^{\prime}$ & 0.56 & 0.54 & 0.57 & 0.49 & 0.55 & 0.56 & 0.59 & 0.55 \\
\hline Informative sites/base & 0.131 & 0.118 & 0.115 & 0.089 & 0.078 & 0.140 & 0.141 & 0.119 \\
\hline
\end{tabular}


MP cpDNA phylogeny

9341 aligned bases, length $=4546$ steps

$\mathrm{Cl}=0.70, \mathrm{Cl}^{\prime}=0.54$

$\mathrm{ML}$ and $\mathrm{BI}$ topology:
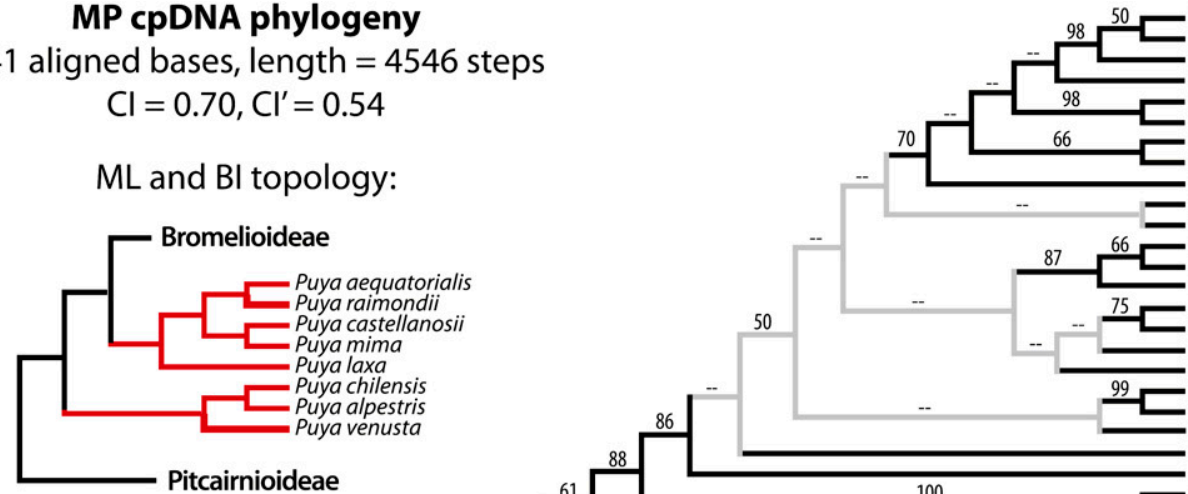

- Wittrockia superba Eduandrea selloana Aechmea organensis Canistropsis billbergioides Edmundoa perplexa

$66 \quad$ Aechmea nudicaulis - Billbergia decora - Aechmea racinae

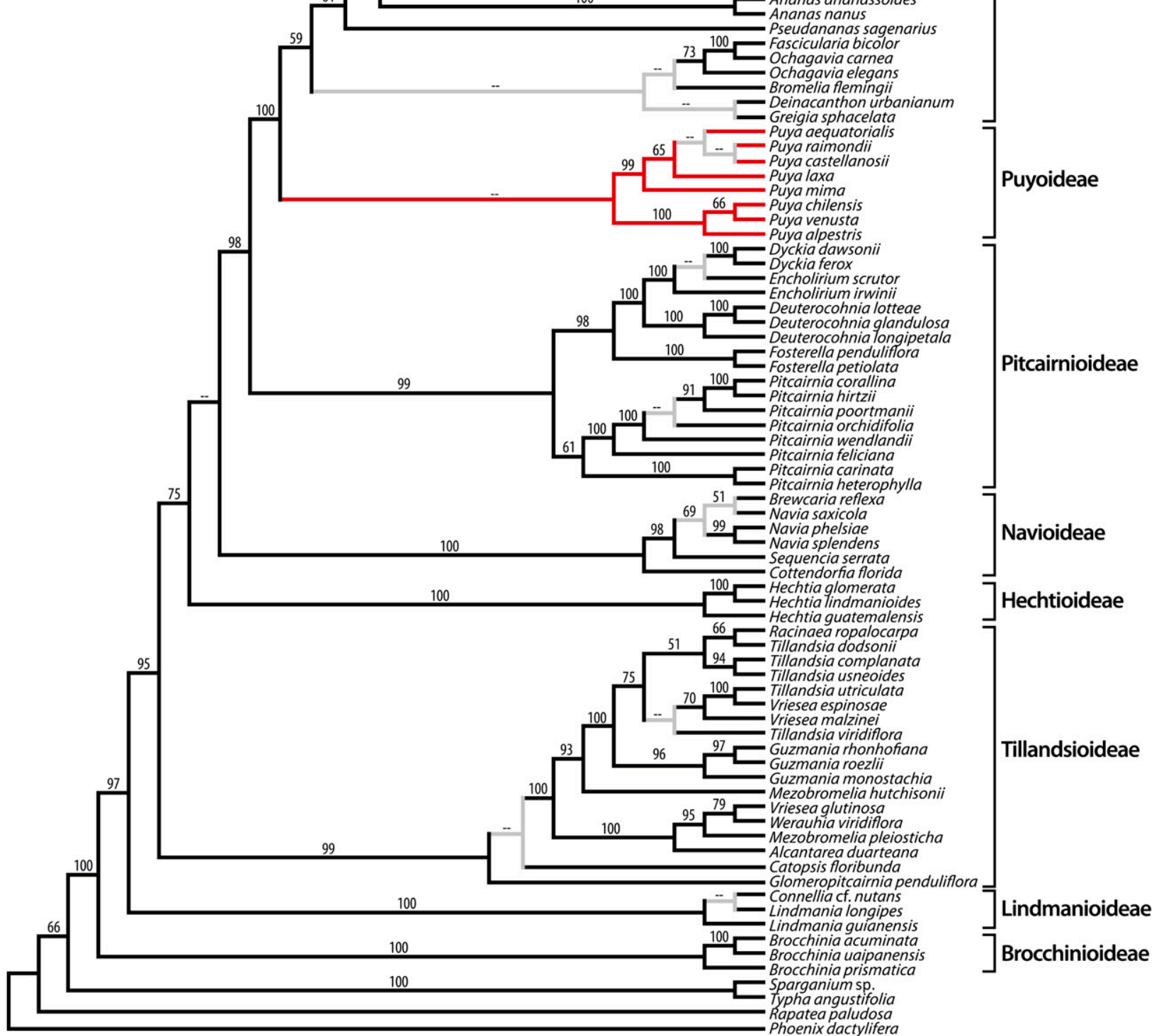

Fig. 3. Maximum-parsimony (MP) majority-rule phylogeny based on eight plastid loci; figure also shows the MP strict consensus tree, in which the

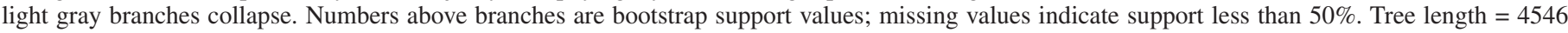

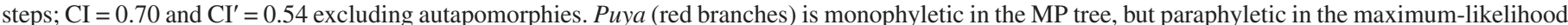
(ML) and Bayesian inference (BI) trees (see inset).

based on the combined data set. Although ILD tests showed apparently significant differences in phylogenetic structure between some pairs of regions, such differences only occurred in comparisons when one or both regions with relatively small numbers of phylogenetically informative sites (Table 1). Furthermore, for each region, the MP strict-consensus tree did not 
diverge from the combined-data phylogeny at nodes well supported ( $\geq 90 \%$ bootstrap support) in the former.

For maximum-likelihood analysis, the AIC identified the optimal models as TVM $+\Gamma$ for $n d h F$; TVM $+\mathrm{I}+\Gamma$ for $m a t K$, trnL (plus intron), atpB, and rps 16; and GTR $+\mathrm{I}+\Gamma$ for $p s b A$ trnL and rpl32. The maximum-likelihood and Bayesian trees were nearly identifical to each other in topology and mostly congruent with the MP majority-rule tree, but placed Bromelioideae in a paraphyletic Puya, sister to the non-Chilean taxa (Figs. 3-5). Both ML and BI placed Hechtia sister to Navioideae-Pitcarnioideae-Puyoideae-Bromeliodeae, congruent with the MP tree. Both placed Catopsis sister to Glomeropitcairnia at the base of the tillandsioids (Figs. 4, 5). The four areas of greatest phylogenetic uncertainty within bromeliads-as judged by differences in topology among trees or the degree of resolution within each tree-correspond to the portions of those trees with exceedingly short branch lengths, including (1) earlydivergent bromelioids, (2) late-divergent bromelioids, (3) relationships among Chilean and non-Chilean Puya, and (4) relationships among Catopsis, Glomeropitcairnia, and all other tillandsioids (Figs. 3, 5). Conflicts among the three phylogenies generally did not occur at nodes that are well supported by each individually.

Molecular clocks and dating-Cross-verification of a penalized-likelihood calibration of the $n d h F$ ML tree across monocots showed that smoothing parameters between 50 and 100 yielded very similar, nearly minimal sums of the squared deviations between the observed and expected branch lengths derived by jackknifing each branch. Within that range, a smoothing parameter of 75 minimized the variance in the apparent ages of the crown and stem node of Bromeliaceae. We used this value to calibrate the across-monocot tree, producing estimates of the bromeliad stem age as $100.0 \pm 5.2$ million years ago (Ma) (and the corresponding crown age as $19.1 \pm 3.4 \mathrm{Ma}$ (Fig. 6). These dates were then employed to calibrate the eight-locus bromeliad tree; cross verification produced a smoothness parameter of 100. The resulting chronogram (Fig. 7) resolved cladogenetic events within Bromeliaceae from 19.1 to 0.64 Ma. The standard deviation of estimated ages for individual nodes generally varied from 0.5 to $2 \mathrm{Myr}$, with smaller estimated amounts of variation due to phylogenetic uncertainty in nodes closer to the present (Fig. 7). Regression of estimated ages for several representative nodes in Bromeliaceae from the eight-locus tree on those from the across-monocots phylogeny (Table 2) yielded excellent agreement between the two sets of estimates $(y=$ $1.060 x-0.032, r^{2}=0.80, P<0.0001$ for $\left.25 \mathrm{df}\right)$.

Historical biogeography-Reconstruction of ancestral areas using MP, BI, and S-DIVA generally agreed with each other, with the exception of a few nodes detailed below (Fig. 8). Based on our eight-locus chronogram and biogeographic reconstruction using MP, we infer that bromeliads arose in the Guayana Shield ca. $100 \mathrm{Ma}$, based on the restriction to this ancient craton-and in most cases, to highly leached marine sandstones of the overlying Precambrian Roraima Formation-of Brocchinioideae and Lindmanioideae, nested sequentially at the base of the family. Brocchinioideae diverged from the ancestor of all other bromeliads ca. 19.1 Ma, and extant species of Brocchinia began to diverge from each other ca. 13.1 Ma (Fig. 8). All other extant bromeliad subfamilies began diverging from each other slightly before that, with the stem lindmanioids diverging from the ancestor of other bromeliads ca. 16.3 Ma. The stem tilland- sioids arose shortly after that, ca. 15.4 Ma (Fig. 8). Based on MP, it is unclear whether tillandsioids arose on the northern littoral of South America, in the Andes, or in Central America (Fig. 8). Catopsis, sister to Glomeropitcairnia with it sister to the remaining tillandsioids, today grows in the Guayana Shield as well as the north coast of South America, the Caribbean, Central America, and southern Florida, but appears to have arisen in Central America (Fig. 8). Glomeropitcairnia is endemic to the Lesser Antilles, Trinidad, and Tobago, and the north coast of Venezuela, and appears to have diverged from Catopsis about 14.0 Ma. The ancestor of the remaining members of the subfamily - which we term the core tillandsioidsappears to have arisen in the Andes about 14.2 Ma, with the modern genera beginning to diverge from each other ca. $8.7 \mathrm{Ma}$, with evolution mainly in the Andes but with several subsequent invasions of Central America, the northern littoral of South America, and the Caribbean (Fig. 8).

Hechtia arose ca. 16.6 Ma and invaded Central America independently (Fig. 8). Extant species of Hechtia began differentiating from each other ca. 10.3 Ma. About 15.0 Ma, Navioideae arose in the Guayana and/or Brazilian Shields, with restriction to the Guayana Shield after 10.4 Ma, corresponding to the endemism there of Brewcaria, Navia, and Sequencia and of Cottendorfia to the Brazilian Shield.

The common ancestor of the three remaining subfamilies evolved about 15.0 Ma in the Andes (Fig. 8), where Pitcairnia grows from near sea level to above treeline (with scattered occurrences elsewhere in the Guayana Shield and southeastern Brazil), Fosterella grows mostly at midelevations in mesic sites (with disjunct occurrences in Central America), Dyckia grows in drier sites from mid to high elevations and extends into the Brazilian Shield and the Rio de la Plata basin (including the Gran Chaco within the latter), and Deuterocohnia occurs as cushion plants in arid, high-elevation sites just south of the "knee" of the Andes, in southern Bolivia and northern Argentina (Fig. 9). Pitcairnioideae arose ca. 13.4 Ma; Pitcairnia, ca. 12.0 Ma; Fosterella, ca. 11.3 Ma; and Deuterocohnia, ca. 8.5 Ma. Based on the taxa included in this study, the lineage leading to Pitcairnia feliciana dispersed to Guinea in west Africa from the Andes sometime in the last 9.3 Myr. Dyckia and Encholirium (the latter restricted to northeastern Brazil) form a clade sister to Deuterocohnia and apparently invaded the Brazilian Shield from the Andes, beginning 8.5 Ma (Figs. 8, 9). Given the geographic overlap of Deuterocohnia, Dyckia, and Fosterella in south-central Bolivia (Fig. 9), it is likely that key cladogenetic events in Pitcairnioideae occurred there.

The common ancestor of Puya and the bromelioids arose about 13.4 Ma in the Andes (Fig. 8). Ancestral Puya diverged from the ancestral bromelioids ca. 10.1 Ma, with Puya splitting almost immediately (10.0 Ma) into two clades distributed in the Andes in low-elevation Chile vs. the rest of the cordillera at mid to high elevations. Present-day species of Puya began to diverge from each other during the last 3.5 Myr in the Andes, and during the last 2.5 Myr in Chile (Fig. 8). In the ML, BI, and MP majority-rule trees, a clade of five small bromelioid genera-mostly from Chile and the southern Andes-are sister to the remaining members of Bromelioideae (Fig. 8). Three of these genera (Fascicularia-Ochagavia and Greigia) are partly or wholly restricted to temperate regions at low elevations in the southern Andes, including low-elevation habitats just above high tide in Fascicularia bicolor and Ochagavia litoralis in continental Chile, and O. elegans in the Juan Fernandez Islands. Greigia grows in montane habitats from Central America to the Andes, and in the 
ML phylogeny

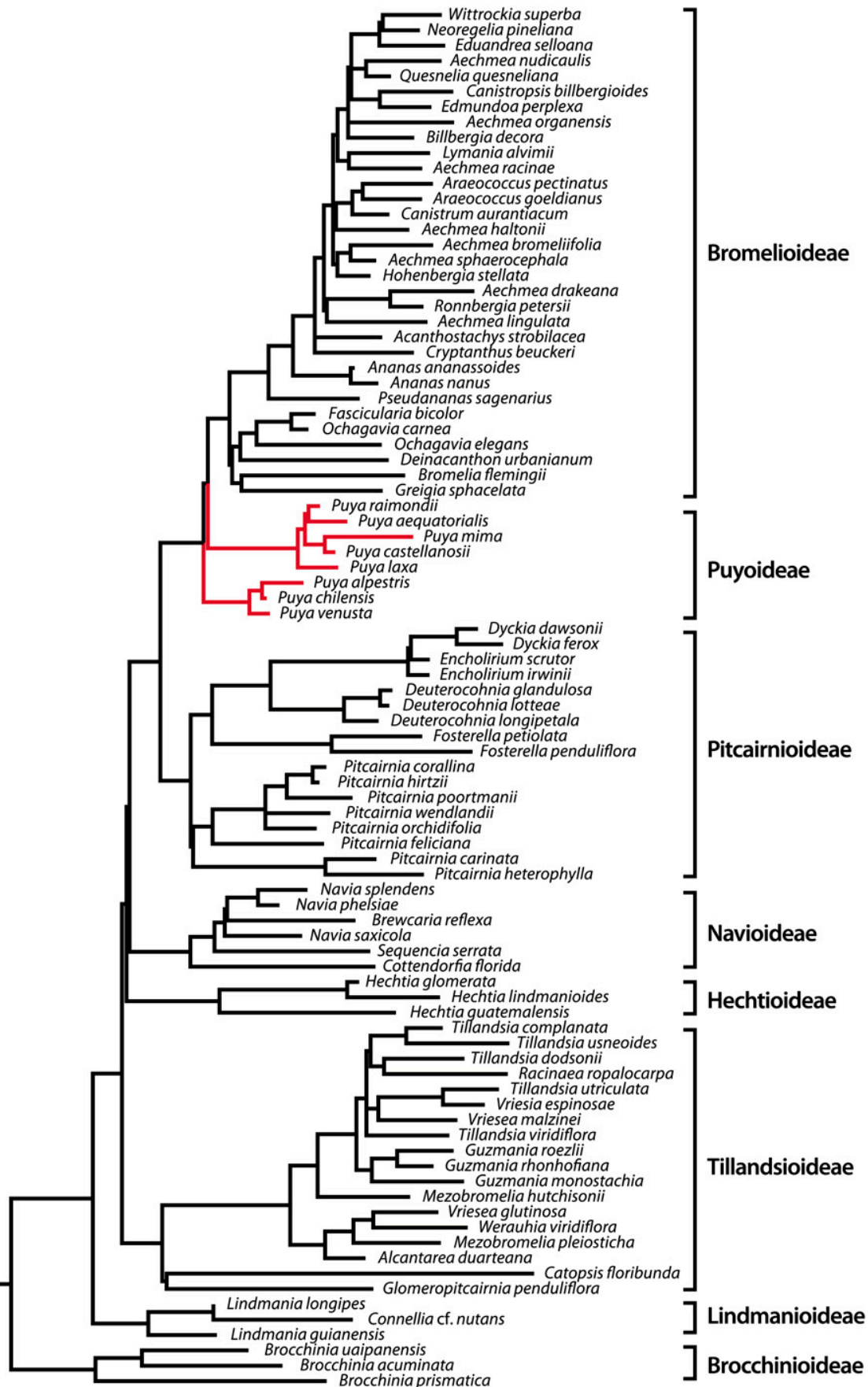

Fig. 4. Maximum-likelihood (ML) phylogram for Bromeliaceae based on concatenated sequenced data. Branch lengths are proportional to the inferred number of nucleotide changes down each branch. Puya (red branches) in paraphyletic in the ML tree, but monophyletic in the MP tree.

understory of humid deciduous and evergreen forests in southern Chile and the offshore Juan Fernandez Islands. Two other genera-monotypic Deinocanthon and species-rich Bromeliagrow in the Gran Chaco (the southwestern portion of the Rio de la Plata basin, adjacent to the Andes) and throughout the Neotropics at low elevations, respectively (Fig. 8).

The remaining bromelioids form the "Brazilian Shield clade", which arose in the Brazilian Shield ca. 10.1 Ma via dispersal from the Andes (Fig. 8). Members of this clade subsequently dispersed repeatedly outside this region, notably in Ananas,
Aechmea, Araeococcus, Billbergia, Neoregelia, and Ronnbergia, but most taxa are restricted to a narrow portion of the Brazilian Shield near the southeastern coast of Brazil, running ca. $1500 \mathrm{~km}$ from Minas Gerais to Rio Grande do Sol. This area includes the Brazilian Highlands (Serra do Mar and the more inland Serra da Mantiqueira) and adjacent coastal plain, with their extremely humid, highly diverse Atlantic rain forests and cloud forests, restingas on sandy soils, mangroves, campos de altitude, and drier vegetation inland (e.g., campos rupestres on rocky outcrops). The bromelioid tank-epiphyte clade-sister to 


\section{BI phylogeny}

BI posterior probability below
ML bootstrap support above/

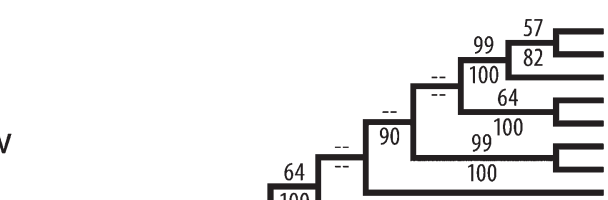

Wittrockia superba

Neoregelia pineliana

Eduandrea selloana

Aechmea nudicaulis

Quesnelia quesneliana

Canistropsis billbergioides

Edmundoa perplexa

Aechmea organensis

Aechmea organensis

- Araeococcus goeldianus

Araeococcus pectinatus

Canistrum aurantiacum

Aechmea racinae

Lymania alvimii

- Aechmea bromeliifolia

Aechmea sphaerocephala

Hohenbergia stellata

Aechmea haltonii

Aechmea drakean

Aechmea drakeana

Ronnbergia petersi

Cryptanthus beuckeri

Acanthostachys strobilacea

Ananas ananassoides

Ananas nanus

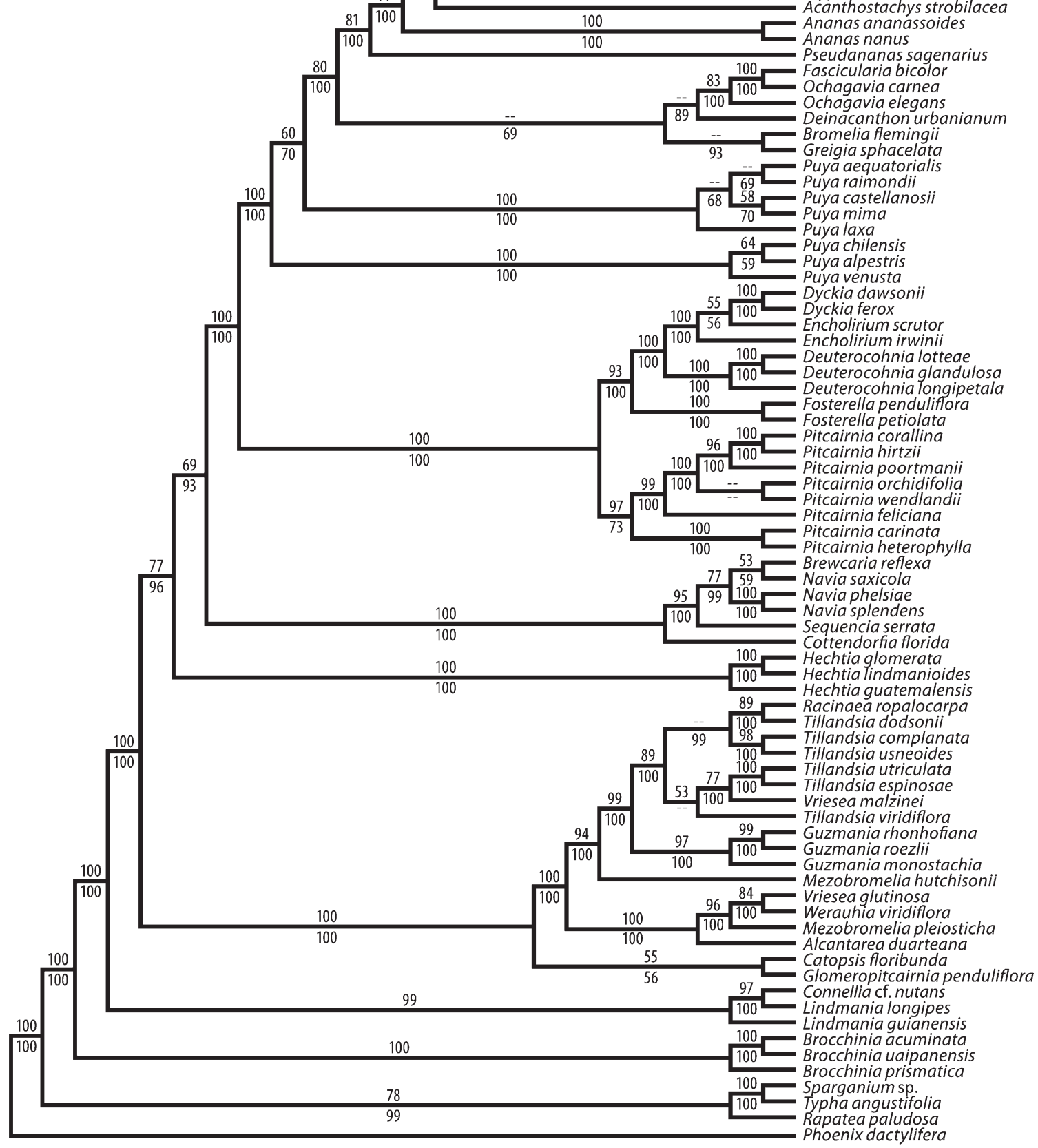

Bromelioideae

Puyoideae

Pitcairnioideae

Tillandsioideae

]Lindmanioideae

Brocchinioideae ree. 


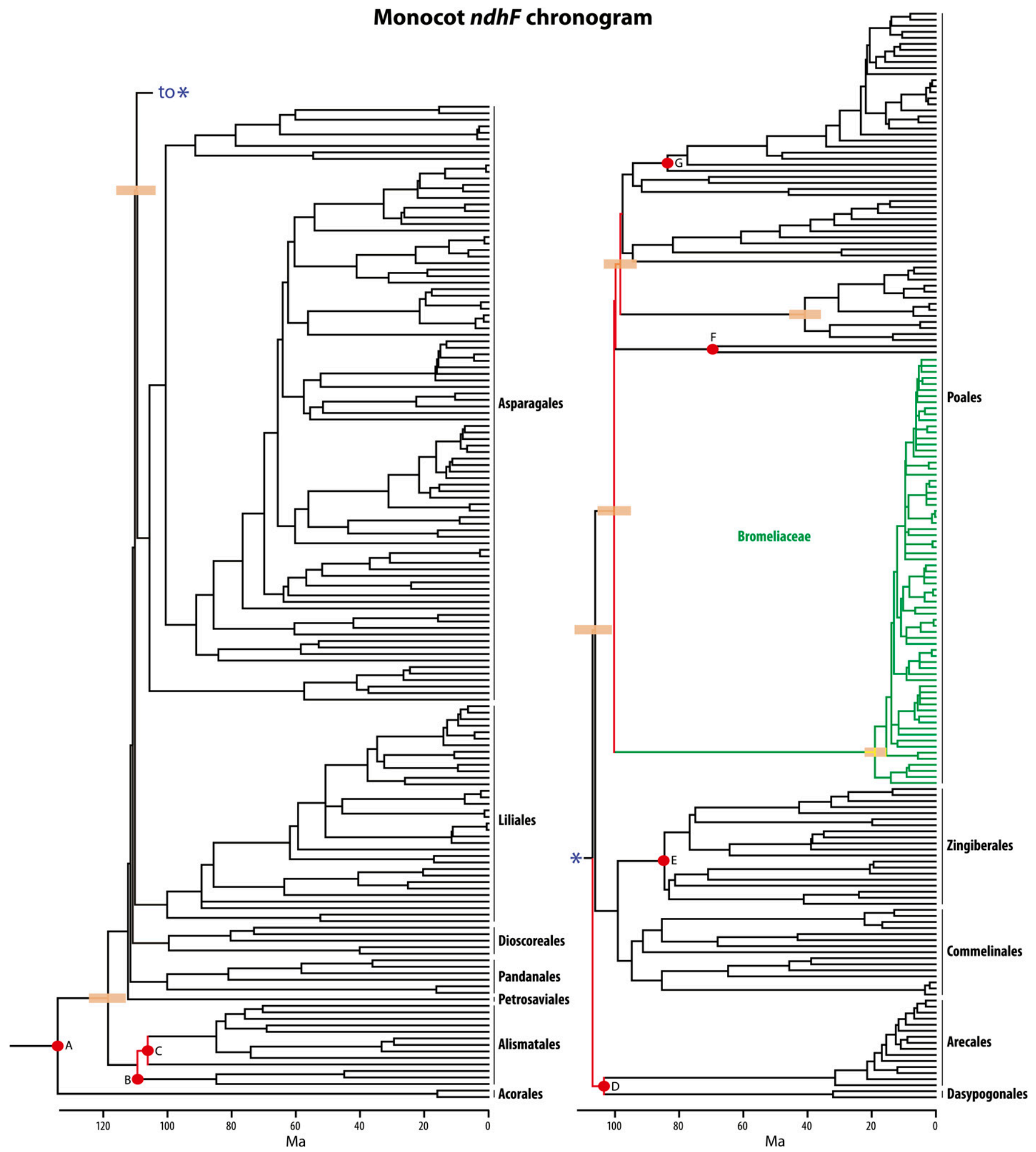

Fig. 6. Cross-verified penalized-likelihood chronogram across monocots based on the maximum-likelihood analysis of $n d h F$ sequence variation. A $=$ age of monocot root = $134 \mathrm{Ma}$ (Janssen and Bremer, 2004): B-G = ages of the six Cretaceous fossils (Givnish et al., 2004; Janssen and Bremer, 2004) used to calibrate the monocot phylogeny against time. Bromeliaceae are highlighted in green. Tan boxes indicate $\pm 1 \mathrm{SD}$, based on bootstrap resamplings, around the estimated ages of several key nodes (red dots), including the core monocots (excluding Acorales and Alismatales), commelinid monocots, order Poales, families Bromeliaceae and Rapateaceae, and remaining Poales sister to Rapateaceae. Red branches indicate those whose topology was constrained based on the plastome tree of Givnish et al. (2010). 
Cryptanthus-Acanthostachys - is nearly restricted to this region and arose 9.1 Ma, with present-day taxa diverging from each other ca. 5.5 Ma (Fig. 8).

Reconstruction of the geographic spread of bromeliads under Bayesian inference tells largely the same story. Bayesian inference is, however, somewhat more specific than maximum parsimony about the likely origins of the tillandsioids and navioids. This portion of the tree is the largest that is not fully resolved biogeographically under MP, involving the rapid-fire divergence of four major lineages between 15.4 and 15.0 Ma, and accounting today for all but $2 \%$ of all bromeliad species. Bayesian inference reconstructed this portion of the bromeliad spine as being most probably Andean in origin (Fig. 8). Together with the BI reconstruction of the distribution of the stem tillandsioids and navioids, this suggests that tillandsioids arose in the Andes with many subsequent dispersals to other regions, especially Central America, the northern littoral of South America, and the Caribbean. It also suggests that ancestral navioids were, at some point, restricted to the Guayana Shield, with later dispersal or vicariance leading to occupancy of the Brazilian Shield by Cottendorfia (Fig. 8). BI suggests that the Guayana Shield or the Andes characterized the stem group for all bromeliads except Brocchinioideae and Lindmanioideae. Maximum parsimony instead points to this group's origin-as well as that of the common ancestor of Hechtioideae and its sister groupbeing in the Guayana Shield, Andes, or Central America. Maximum parsimony identifies these three areas, as well as the northern littoral of South America and the Caribbean, as possible ancestral areas for Tillandsioideae and Catopsis-Glomeropitcairnia (Fig. 8). Maximum parsimony identifies the Guayana Shield, Brazilian Shield, Andes, and Central America as possible ancestral areas for Hechtioideae and the common ancestor of Hechtioideae and the subfamilies to which it is sister. Bayesian inference is less certain than MP in reconstructing the biogeographic origins of Pitcairnia, assigning it to one of five areas while MP assigns it to the Andes. Bayesian inference is also less certain than MP in reconstructing the ancestral area of Bromelia and Greigia, making it equally likely that their common ancestor arose in Central America, the northern littoral of South America and the Caribbean, or the Andes. Bayesian inference reconstructs the stem region of Bromelioideae as being nearly equally likely to be the Andes or Brazilian Shield, with the taxa in the clade sister to the Brazilian Shield clade all being native to the southern Andes/Chile and the Gran Chaco, in the extreme southwest of the Rio de la Plata basin.

Finally, when outgroups are excluded, S-DIVA implies that the Guayana Shield is the ancestral area for Bromeliaceae, Brocchinioideae, and Lindmanioideae (Fig. 8). S-DIVA estimates the chance that the ancestral area for Tillandsioideae is the northern littoral of South America or Caribbean as 29\%; that area fused to the Andes, $31 \%$; and that same area fused to Central America, $40 \%$. The chance that the ancestor of Tillandsioideae and its sister groups arose in the Guayana Shield fused to the northern American littoral and Caribbean is 31\%; in the Andes alone, 33\%; and in Central America alone, 36\%. Catopsis-Glomeropitcairnia originated in Central America fused to the northern littoral of South America and Caribbean (Fig. 8). S-DIVA identifies the Andes fused to Central America as the ancestral area for Hechtioideae and its sister clade and the ancestral area of Navioideae and its sister clade as the Andes fused to the Brazilian Shield. Under this approach, Navioideae arose in the Guayana Shield fused to the Brazilian Shield, while the extant bromelioids arose in the Andes fused to the Brazilian
Shield (Fig. 8). At other nodes, S-DIVA without outgroups usually reconstructs the same ancestral areas as MP and BI, except for Pitcairnia, which it implies arose in the Andes. Including outgroups changed the S-DIVA reconstruction little except at the base of Bromeliaceae, where a greater range of possible source regions were identified.

\section{DISCUSSION}

Phylogenetic relationships - Our analysis-based on more sequence data per taxon and wider sampling of genera than any previous study-supports the eight-subfamily classification advanced by Givnish et al. (2007) based on $n d h F$ sequences (Fig. 2), and further clarifies the relationships among those subfamilies (Figs. 3-5). In the MP strict consensus, six subfamilies received bootstrap support $\geq 96 \%$. Bromelioideae had $55 \%$ bootstrap support; Puyoideae, $<50 \%$. Support for five subfamilies increased relative to the $n d h F$ study, but that for Lindmanioideae, Puyoideae, and Bromelioideae decreased as a result of the greater breadth of taxonomic sampling, including Connellia, the three Chilean Puya species, and several Chilean bromelioids. When we excluded the latter from our analysis, bootstrap support for both Puyoideae and Bromelioideae jumped to 100\%; when we excluded Connellia, support for Lindmanioideae also reached $100 \%$.

The MP, ML, and BI trees all support a stepped phylogeny for the bromeliad subfamilies: (Brocchinioideae, (Lindmanioideae, (Tillandsioideae, (Hechtioideae, (Navioideae, (Pitcairnioideae, (Puyoideae, Bromelioideae))))))). In Givnish et al. (2007), Hechtia instead formed a hard trichotomy with Tillandsioideae and all subfamilies sister to and including Navioideae. Our results clarify the position of Hechtioideae and, thus, the relationships of all bromeliad subfamilies. Support for the position of Navioideae is less than $50 \%$ under maximum parsimony, compared with $69 \%$ under maximum likelihood and $93 \%$ under Bayesian inference (Fig. 5).

Our results concur with the general finding that tree resolution and support for most angiosperm clades increase in combined vs. separate plastid gene analyses (e.g., Soltis et al., 1998, 2000; Savolainen et al., 2000; Olmstead et al., 2000, 2001; Bremer et al., 2002; Chase et al., 2006; Graham et al., 2006). Furthermore, simulations show that phylogenetic resolution and support can also improve with more taxa sampled within a given clade (Hillis, 1996; Graybeal, 1998), particularly when taxa are added strategically to break up long branches (Hendy and Penny, 1989; Leebens-Mack et al., 2005). While a number of ILD tests suggest that some plastid regions sequenced in this study show conflict in phylogenetic structures, we believe that this conflict is illusory. First, the plastid genome is inherited as a unit, so individual plastid regions should not conflict in the phylogenetic history their sequences reflect (Doyle, 1992). Second, trees based on each individual region generally do not differ from the combined-data phylogenies at nodes resolved and well supported in the individual-region trees. However, it must be realized that the limited number of informative sites in several data partitions (Table 1) result in few resolved and wellsupported nodes in many individual-region trees. For example, we found that sequences for $a t p B-r b c L$ resolve only $40 \%$ of the nodes within Bromeliaceae; of those, $63 \%$ have bootstrap support from 50 to $90 \%$, and only $21 \%$ ( 8 nodes) have bootstrap values greater than $90 \%$. The whole point of concatenating plastid data are that individual genes and spacers each contain 
Bromeliad 8-locus chronogram

bars indicate $\pm 1 \mathrm{~s}$. d. of node age
Wittrockia superba Neoregelia pineliana

Eduandrea selloana

Eduandrea selloana

Aechmea nudicaulis

Quesnelia quesneliana

Edmundoa perplexa

Aechmea organensi

Billbergia decora

Lymania alvimii

Lymania alvimii

- Araeocococcus pectinatus

Araeococcus pectinatus Araeococcus goeldianus Canistrum aurantiac um Aechmea haltonii

Aechmea bromeliifolia Aechmea sphaerocephala Hohenbergia stellata Aechmea drakean Ronnbergia petersii - Aechmea lingulata Acanthostachys strobilacea

Cryptanthus beuckeri Ananas ananassoides Ananas nanus

Pseudananas sagenarius

- Fascicularia bicolor

- Fascicularia bicolor - Ochagavia carnea Deinacanthon urbanianum

Bromelia flemingii

Greigia sphacelata

Puya raimondii

Puya aequatorialis

- Puya mima

Puya castellanosii

- Puya laxa

Puya alpestris

Puya chilensis

Puya venusta

- Dyckia dawsonii

Dyckia ferox

Encholirium scrutor Encholirium irwinii

- Deuterocohnia lotteae

Deuterocohnia glandulosa

Deuterocohnialongipetala Fosterella petiolata Fosterella penduliffora - Pitcairnia corallina

- Pitcairnia corallina

Pitcairnia hirtzii

Pitcairnia poortmani

Pitcairnia wendlandi

Pitcairnia orchidifolia

Pitcairnia feliciana Pitcairnia carinata Pitcairnia heterophylla

- Navia splendens

Navia phelsiae

Brewcaria reflexa Navia saxicola

Sequencia serrata

Cottendorfia florida

Hechtia glomerata Hechtia lindmanioides Hechtia guatemalensis Tillandsia complanata Tillandsia usneoides Tillandsia dodsonii Racinaea ropalocarpa Vriesia espinosae Vriesia espinosae Viresea malzinei Tillandsia viridiflora Guzmania roezlii Guzmania rhonhofiana Guzmania monostachia Mezobromelia hutchisonii Vriesea glutinosa Werauhia viridiffora Mezobromelia pleiosticha - Alcantarea duarteana - Alcantarea duartean Glomeropitcairnia penduliflora Lindmania longipes Connellia cf. nutans Lindmania guianensis Brocchinia uaipanensis Brocchinia acuminata - Brocchinia a prismatica

\section{Bromelioideae}

Puyoideae

Pitcairnioideae

$=$

Navioideae

$\exists$

Hechtioideae

$=$

Tillandsioideae

Lindmanioideae

\rceil Brocchinioideae 
TABLE 2. Stem and crown ages of bromeliad subfamilies and subsets thereof, based on penalized-likelihood analyses of the acrossmonocots $n d h F$ tree and the eight-locus plastid phylogeny.

\begin{tabular}{lccrrr}
\hline \hline & \multicolumn{2}{c}{ Stem age (Myr) } & & \multicolumn{2}{c}{ Crown age (Myr) } \\
\cline { 2 - 3 } Taxon & $n d h F$ & 8-locus & & $n d h F$ & 8 -locus \\
\hline Brocchinioideae & 19.1 & 19.1 & & 14.2 & 13.1 \\
Lindmanioideae & 15.6 & & & 16.3 & 8.9 \\
Tillandsioideae & 14.0 & 15.4 & & 11.8 & 14.2 \\
$\quad$ Core tillandsioids & 11.8 & 14.2 & & 6.8 & 8.7 \\
Hechtioideae & 14.0 & 15.2 & & 12.1 & 10.3 \\
Navioideae & 14.0 & 15.0 & & 9.4 & 10.4 \\
$\quad$ Navia-Brewcaria & 9.3 & 8.3 & & 8.6 & 7.0 \\
Pitcairnioideae & 13.3 & 13.4 & & 9.4 & 11.8 \\
$\quad$ Pitcairnia & 13.2 & 12.0 & & 9.4 & 11.8 \\
Puyoideae & 9.8 & 10.1 & & 8.7 & 10.0 \\
Bromelioideae & 9.8 & 10.1 & & 9.5 & 8.9 \\
$\quad$ Brazilian Shield clade & 9.5 & 9.1 & & 9.3 & 7.4 \\
$\quad$ Tank epiphyte clade & 7.1 & 5.7 & & 5.7 & 5.5 \\
Puyoideae + Bromelioideae & 13.2 & 13.4 & & 10.1 & 10.0 \\
$\quad$ Puy + Brom + Pitc & 13.4 & 15.0 & & 13.2 & 13.4 \\
\hline
\end{tabular}

relatively little phylogenetic signal in slowly evolving bromeliads, so several regions must be sampled to obtain a reliable phylogenetic estimate. Finally, the pairs of plastid regions showing "significant" conflict in the ILD tests in this study are those in which one or both regions have few informative sites (Table 1). Incongruence length difference tests involving such regions are inherently unstable due to sampling error in determining the universe of characters sampled; branches supported by limited data can easily be reversed in larger data sets as the signal in individual bases is overruled by that in additional bases sampled (e.g., see Darlu and Lecointre, 2002). The fact that the apparent conflict between regions occurred only among those involving one or two regions with limited numbers of informative characters in the combined analysis, combined with the fact that such conflict should be most likely when limited numbers of characters are sampled in a phylogeny with short branches argues that the "conflict" detected by ILD tests for some pairs of regions is simply a sampling artifact and should thus be ignored.

Implications for classification-Our results confirm that the traditional division of Bromeliaceae into three subfamiliesPitcairnioideae s.l., Tillandsioideae, and Bromelioideae (Harms, 1930), defined by possession of winged seeds, plumose seeds, and fleshy fruits, respectively - must be abandoned. Pitcairnioideae sensu Harms (1930) is paraphyletic and must be split into Brocchiniodeae, Lindmanioideae, Hechtioideae, Navioideae, Pitcairnioideae s.s., and Puyoideae to produce monophyletic subfamilies. Each of the new subfamilies is easily diagnosed based on morphology (Givnish et al., 2007), and the relationships among subfamilies found here are consistent with those demonstrated in other recent analyses (Terry et al., 1997; Crayn et al., 2000, 2004; Horres et al., 2000, 2007; Givnish et al., 2004, 2007; Barfuss et al., 2005; Schulte et al., 2005;
Schulte and Zizka, 2008), but better resolved and more taxonomically inclusive.

Our results raise the question of Puya's monophyly. Puya is monophyletic but weakly supported under MP, and paraphyletic under ML and BI (Figs. 3-5). Jabaily and Sytsma (2010) found support for the monophyly of Puya in a combined analysis of sequences for three plastid regions (matK, rpsl6, trnS$\operatorname{trn} G)$ and one single-copy nuclear gene $(P h y C)$ with a far more extensive sampling of the genus. PhyC alone supports the monophyly of Puya, while the plastid data do not contradict monophyly. Given these results, Puya's monophyly in our MP trees, and Puya's possession of a striking morphological synapomorphy-e.g., petals that spiral tightly after anthesis (Smith and Downs 1974) - we consider Puya and Puyoideae to be monophyletic, but recognize that further tests of relationships among Chilean Puya, other Puya, and Bromelioideae would be useful. The possibility of sinking Puya into Bromelioideae, as suggested by Terry et al. (1997), is not appealing, given that both Bromelioideae and Puyoideae as currently defined are characterized by obvious morphological synamorphies, while the clade consisting of both subfamilies appears to lack such defining traits.

Our findings add to a growing case, developed by Schulte et al. (2005, 2009), Schulte and Zizka (2008), Zizka et al. (2009), and Jabaily and Sytsma (2010) that three small terrestrial genera from temperate Chile and the southern Andes (Fascicularia, Ochagavia, Greigia) are among the earliest-divergent members of subfamily Bromelioideae, together with two small terrestrial genera, wide-ranging Bromelia and monotypic Deinacanthon endemic to the semiarid Gran Chaco of southern Bolivia, Paraguay, and northern Argentina. These genera form a weakly supported clade in our ML, BI, and MP majority-rule trees, and a largely unresolved grade in our MP strict consensus tree (Figs. 3-5). All three analyses identify a further grade of small terrestrial genera sister to the remaining bromelioids, including Pseudananas, Ananas, and Cryptanthus; the single species of epiphytic (but nontank forming) Acanthostachys is closely related to Cryptanthus. Taxa sister to and including Pseudananas form the Brazilian Shield clade (61\% MP bootstrap support, $81 \%$ ML bootstrap support, 100\% BI bootstrap support), which arose $9.1 \mathrm{Ma}$ (see Results). In contrast to our results, Sass and Specht (2010) recovered Ananas and Araeococcus as not being monophyletic. However, this is a result solely of those authors sampling a far greater number of species in the known "trashcan" genus Aechmea; almost surely, their findings will result in the errant Aechmea species being reclassified as members of Ananas or Araeococcus.

Almost all species in the Brazilian Shield clade-represented by the 21 species in our study, sister to and including Aechmea drakeana-A. lingulata-Ronnbergia petersii-form a clade of tank epiphytes endemic to the Brazilian Shield, based on the possession of tanks and the epiphytic habit by almost all these species (see Smith and Downs, 1974, 1977, 1979; Schulte et al., 2009). All three analyses support this clade, with $<50 \%$ support under MP, 73\% under ML, and 99\% under BI (Figs. 3-5). Among these taxa, only Araeococcus pectinatus lacks a tank; only Aechmea bromeliifolia, A. sphaerocephala, and Billbergia

Fig. 7. Cross-verified penalized-likelihood (PL) chronogram for bromeliad evolution based on the maximum-likelihood phylogeny, using the crown and stem ages derived from the across-monocots PL analysis (see Fig. 6). Each magenta bar indicates \pm 1 SD around the estimated age of the corresponding node based on bootstrap resamplings. 


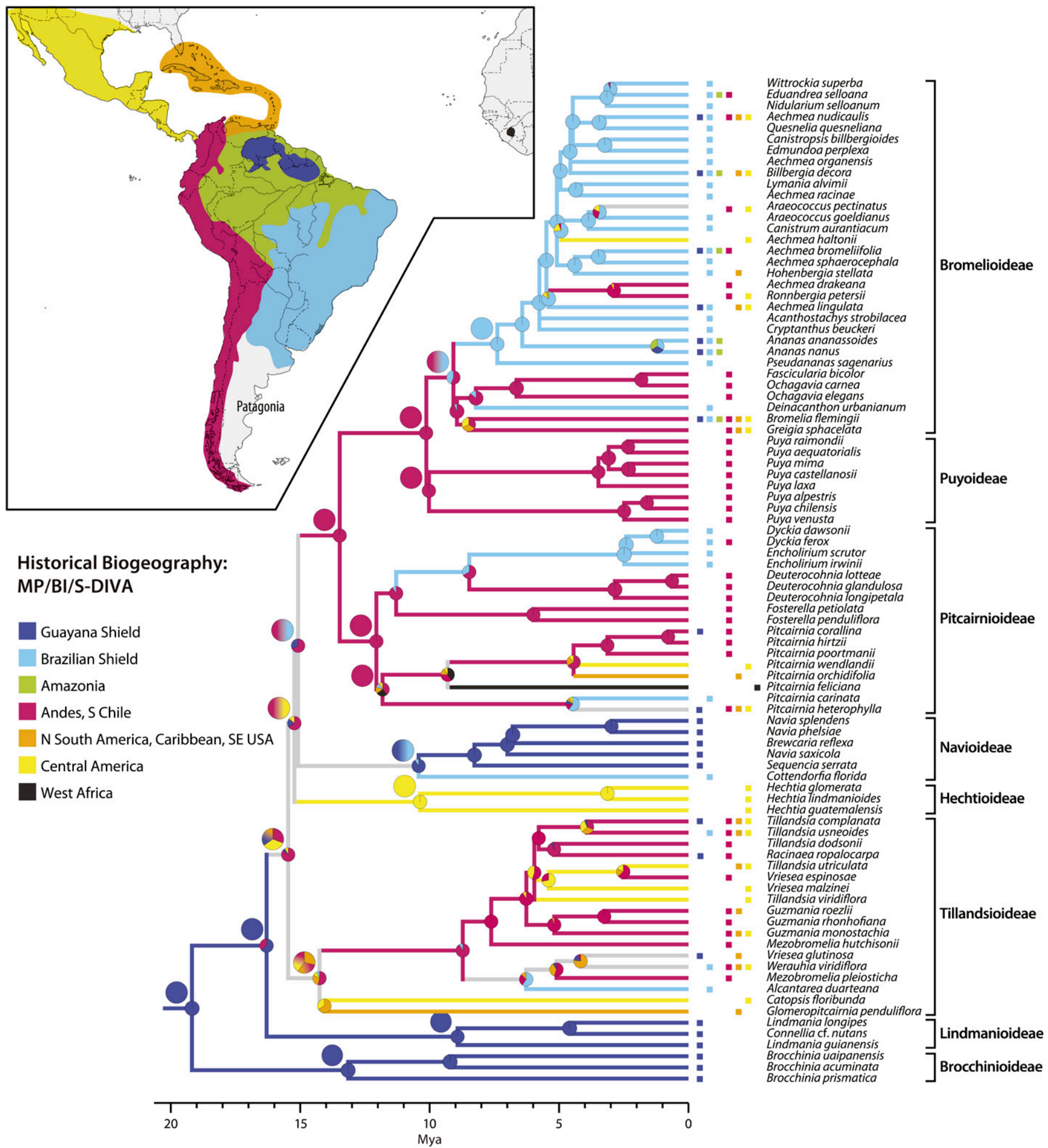

Fig. 8. Geographic evolution of Bromeliaceae calibrated against time. Present-day distribution of individual species (or of genera, in cases where wide-ranging groups are represented by one or two placeholder taxa) indicated by colored boxes. Branch colors indicate the inferred distributions of ancestral taxa under maximum parsimony (MP); gray indicates ambiguity. Pie diagrams at nodes indicate the inferred ancestral distributions under Bayesian inference (BI), with width of wedges delimited by black lines showing likelihood of alternative inferences. Larger pie diagrams displaced northwest of nodes indicate the inferred ancestral distributions under S-DIVA, with wedges delimited by black lines showing likelihood of alternative inferances, and a blend of colors within wedges signifying vicariance involving a fusion of two regions represented by those colors. Analyses involving the possible fusion of more than two areas yield similar results except for a few backbone nodes. 


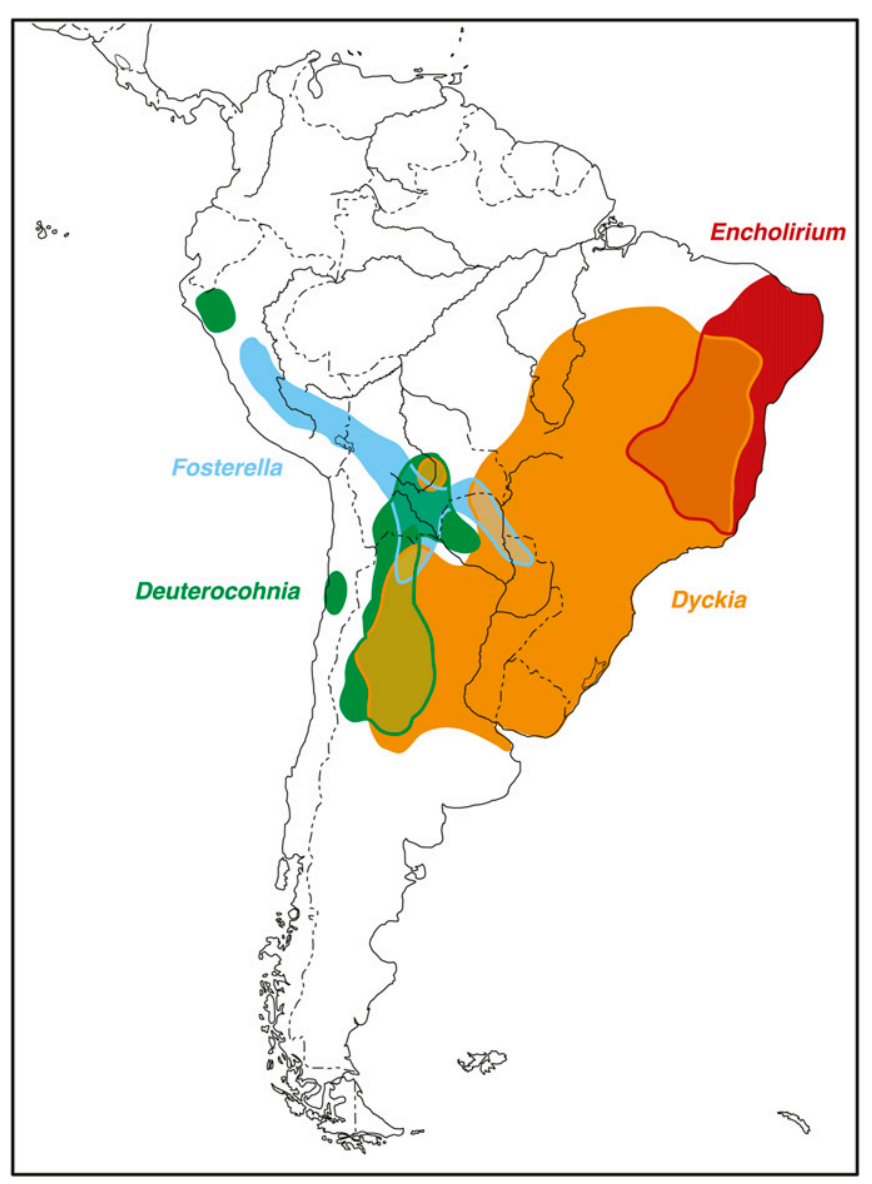

Fig. 9. Geographic distribution of genera of Pitcairnioideae minus Pitcairnia; the latter is broadly distributed throughout the Andes and nearby regions. Note the regional overlap of three of the four genera in the "knee" of the Andes.

decora are almost never epiphytic; and only Aechmea drakeana, A. haltoni, and Ronnbergia petersii are not native, at least in part, to the Brazilian Shield (Smith and Downs, 1974, 1977, 1979). Schulte et al. (2009) similarly found tanks ubiquitous (except in Araeococcus flagellifolius) in a clade of 28 core bromelioids sister to Aechmea drakeana-Hohenbergia eriostachya based on sequence data from one nuclear gene $(P R K)$ and five plastid loci. That clade has a membership consistent with our bromelioid tank-epiphyte clade, but also included species of Androlepis, Neoglaziovia, Portea, and Ursulaea-four of the 12 genera not included here. Schulte et al. (2009) found that two other genera-Orthophytum and Fernseea, both speciespoor terrestrial groups from the Brazilian Shield-are part of our Brazilian Shield clade. Fernseea is sister to all remaining elements of the Brazilian Shield clade, and Orthophytum is sister to Cryptanthus; only one species of Fernseea from these three genera are epiphytes or tank-formers (Schulte et al., 2009).

Our study generally agrees with Barfuss et al. (2005) on relationships within Tillandsioideae. Consistent with our ML tree, Barfuss et al. (2005) found that Catopsis and Glomeropitcairnia were sister to each other and together sister to all other tillandsioids. Also largely consistent between the two studies is the split of the remaining taxa into the tribes Vrieseeae (Alcantarea, Vriesea, Werauhia) and Tillandsieae (Guzmania, Raci- naea, Tillandsia, Viridantha). However, in our study one species of Vriesea fell into Tillandsieae with $100 \%$ bootstrap support, and Mezobromelia pleiosticha-replacing a misidentified Guzmania variegata sequenced by Barfuss et al. (2005) fell into Vrieseeae with $95 \%$ bootstrap support (Fig. 3).

Brewcaria reflexa appears to be embedded in Navia (Figs. 3, 4). Holst (1997) moved several species from Navia into Brewcaria based on their possessing a spicate or paniculate inflorescence, rather than the capitulate inflorescences seen in other Navia. This decision is not supported in the case of Brewcaria reflexa, the only species of that genus included in this study. Our study confirms the highly polyphyletic nature of Aechmea, with six independent origins indicated by our study. Sass and Specht (2010) found an even greater degree of polyphyly and paraphyly in Aechmea based on a much more extensive sampling of species (150) within Bromelioideae.

In a way, our findings confirm the traditional view that bromelioids and tillandsioids arose from within Pitcairnioideae s.l. (Schimper, 1888; Mez, 1904; Pittendrigh, 1948; Tomlinson, 1969; Smith and Downs, 1974; Benzing et al., 1985; Smith, 1989; Benzing, 1990). Terry et al. (1997) reached a similar conclusion, but had a different view of relationships of bromelioids to tillandsioids and the seeming isolation of Brocchinia because they did not sample two of our subfamilies and undersampled two others. Terry et al. (1997) also concluded that Hechtia was closely allied to Dyckia, Encholirium, Abromeitiella, and Deuterocohnia, rather than being a convergent lineage. Horres et al. (2000) did not exclude a close tie of Hechtia to xeromorphic pitcairnioids and Puya, but their data placed Hechtia in a position consistent with that found here. Givnish et al. (2007) noted that the shared possession of four to six leaf anatomical traits by Hechtia with Puya and the xeromorphic pitcairnioids as a striking instance of concerted convergence.

The classical view that bromelioids and tillandsioids emerged from within Pitcairnioideae s.l. was based not on phylogenetic analysis, but on observing that epiphytism - a highly specialized habit, with several adaptations for life on twigs and branches-is almost absent among pitcairnioids as previously circumscribed. No early writer proposed that Brocchinia or Lindmania were sister to the rest of the family, or that Pitcairnioideae s.l. were not monophyletic. Terry et al. (1997) were the first to conclude that Brocchinia was sister to all other bromeliads and that the traditional Pitcairnioideae were paraphyletic. That view, based on an analysis including exemplars of only 28 of 58 bromeliad genera, is confirmed and greatly amplified by the present analysis.

The remarkably long period of ca. $81 \mathrm{My}$ between the rise of the bromeliads and the divergence of modern lineages from each other suggests that much extinction occurred during the intervening period, and explains the morphologically isolated position of the family and the difficulty, even with extensive molecular data sets, of identifying its sister group (see Givnish et al., 2005, 2007; Chase et al., 2006; Graham et al., 2006). Restriction of Brocchinioideae and Lindmanioideae to the Guayana Shield, the occurrence of some Catopsis and Glomeropitcairnia in or immediately adjacent to the Guayana Shield, and the near restriction to that region of Navioideae, combined with the phylogenetic relationships shown here, place the origin of Bromeliaceae in the Guayana Shield, consistent with the evidence and arguments presented by Givnish et al. (2007). The divergence of most bromelioid genera in just the last 5.5 Myr, coupled with very low rates of molecular evolution in bromeliads, explains the great difficulty investigators have had in ob- 
taining a well-resolved phylogeny for bromelioids (Terry et al., 1997; Horres et al., 2000, 2007; Crayn et al., 2004; Givnish et al., 2004, 2007; Schulte et al., 2005) and the relatively limited and homoplastic morphological variation in this group (Smith and Downs, 1979; Smith and Kress, 1989, 1990; de Faria et al., 2004; Schulte and Zizka, 2008; Sass and Specht, 2010).

Historical biogeography-Our analyses show that bromeliads arose in the Guayana Shield roughly $100 \mathrm{Ma}$, spread from that hyperhumid, extremely infertile center to other parts of tropical and subtropical America starting ca. 15.4 Ma, and arrived in tropical Africa ca. 9.3 Ma. Our PL chronology implies that the extant subfamilies began to diverge from each other beginning only about $19 \mathrm{Ma}$ and that invasion of drier peripheral areas in Central America (Hechtia) and northern South America (Tillandsioideae) began roughly 15.2 to $15.4 \mathrm{Ma}$. Brocchinioideae, Lindmanioideae, and Navioideae except Cottendorfia remained entirely within the Guayana Shield. The northern Andes and Central America were independently colonized by two major lineages: the core tillandsioids (Alcantarea, Tillandsia, Vriesea, Werauhia) beginning about $14.2 \mathrm{Ma}$; and Fosterella, beginning about $11.3 \mathrm{Ma}$. In addition, Puya and the early-divergent bromelioids colonized throughout the Andes, extending into temperate coastal Chile, beginning ca. $10.1 \mathrm{Ma}$ (Fig. 5; all calculated ages based on stem groups). Other groups-including some Pitcairnia and species in several bromelioid genera (e.g., Aechmea, Araeococcus, Neoregelia, Ronnbergia) - also invaded the Andes independently, but we have not sampled enough taxa to estimate the timing and/or numbers of such events reliably. At least five additional colonizations, however, appear to be involved.

Uplift of the northern Andes beginning in the mid-Miocene, causing a shift in the course of the Amazon from a northerly route via the paleo-Orinoco toward Lake Maracaibo to an easterly course toward its present mouth (Hoorn, 1994; Hoorn et al., 1995, 2010; Potter, 1997), appears to correspond roughly to when bromeliad subfamilies began to diverge outside the Guayana Shield. This Andean uplift appears to have occurred at about the same time as the first split of modern hummingbird lineages in the Andes ca. $13 \mathrm{Ma}$, with several other Andean lineages diverging during the Pliocene and Pleistocene (Bleiweiss 1998), just as the uplift of the Columbian Andes accelerated starting ca. 3.9 Ma (Gregory-Wodzicki, 2000).

As the central and northern Andes continued to rise, they were colonized by the largely epiphytic tillandsioids between ca. 14.2 and $8.7 \mathrm{Ma}$, after that subfamily began diversifying in the northern littoral of South America, the Caribbean, and Central America. Speciation in Andean tillandsioids was explosive, resulting in ca. 1250 present-day species (Luther, 2008), more than 60 times the numbers of taxa seen in Brocchinioideae. Tillandsioids today have their great species richness in Andean Colombia, Ecuador, and Peru and range along the length of the Andes, into arid habitats on the Pacific and Caribbean littorals, and into Central America and North America north to Virginia (Smith and Downs, 1977).

How Hechtia colonized arid areas of Central America is unclear. The Isthmus of Panama did not close until roughly 4.43.1 Ma (Ibaraki, 1997; Kirby et al., 2008), so colonization from the Guayana Shield, the Caribbean or Caribbean littoral, or the Andes almost surely involved one or more bouts of long-distance seed dispersal, either directly to Central America, or via a series of arid habitats in the Lesser and Greater Antilles, or on the west slope of the Andes. Such long-distance dispersal ap- pears plausible, given the inferred dispersal of Fosterella from the central Andes to dry forests in Mexico, El Salvador, and Guatemala in Central America (Rex et al., 2007), of Greigia and Ochagavia to the Juan Fernandez Islands and Racinaea to the Galápagos from the Andes (Smith and Downs, 1974), and of Pitcairnia across the tropical Atlantic to West Africa (Givnish et al., 2004, 2007). We favor direct dispersal of ancestral Hechtia to Central America, given the persistence of arid habitats in the Caribbean as well as coastal Peru and Chile, and the absence of Hechtia there. Today, Hechtia is restricted to arid habitats in Central America, while tillandsioids there are more broadly distributed ecologically and are especially diverse in humid montane habitats (see Smith and Downs, 1974, 1977).

Deposition of nutrient-rich Andean sediments in the Amazon basin, separating the Guayana and Brazilian Shields ecologically, accelerated ca. 11.8-11.3 Ma, corresponding to continued uplift of the northern Andes and filling of the vast Pebas wetlands of western Amazonia, as well as erosion finally cutting through the Purus Arch in central Amazonia (Figueiredo et al., 2009). Divergence of monotypic Cottendorfia from remaining Navioideae of the Guayana Shield about 10.4 Ma suggests that Cottendorfia may have arrived in the Brazilian Shield via long-distance dispersal. However, the timing of the deposition of Amazonian sediments separating the Guayana and Brazilian Shields on the Amazonian Platform is close enough in time, and the proximity of both shields close enough in space then that we should not exclude vicariance-short-distance dispersal as an alternative explanation. Three other groups also appear to have colonized the Brazilian Shield: Dyckia-Encholirium from the central Andes 8.5 Ma (Fig. 7); the Brazilian Shield bromelioids, most likely from the southern Andes ca. 9.1 Ma (see below); and certain species of Bromelia, probably from the Amazon basin, also ca. 9.1 Ma (Fig. 8). Individual species of several wideranging genera (e.g., Guzmania, Tillandsia, Vriesea) almost surely colonized the Brazilian Shield from other areas as well.

Our reconstruction suggests that Pitcairnioideae dispersed counterclockwise through time, first from the Guayana Shield to the (northern) Andes and its lowland slopes for Pitcairnia, then to the central Andes for the split between lineages giving rise to Fosterella and to the remaining genera, with a split between the puna cushion-plants of Deuterocohnia and arid-zone Dyckia in south-central Bolivia roughly $9.1 \mathrm{Ma}$, and subsequent dispersal of Dyckia to the Brazilian Shield and its divergence from Encholirium in the Horn of Brazil about 2.4 Ma (Figs. 7 and 8; see also Givnish et al., 2004, 2007).

The cradle of Puya appears to be Andean, but our analysis samples too few species within the genus to locate its geographic origin (see Jabaily and Sytsma, 2010). Jabaily (2009) used AFLP data to argue that Puya spread northward from the southern and central Andes soon after the split from the Chilean taxa. Based on our calculations, that split occurred around 10 $\mathrm{Ma}$, soon after the uplift of the northern Andes began to accelerate. Divergence between Puyoideae and Bromelioideae seems likely to have occurred in and around the southern Andes, given the basal split in Puya between Chilean and Andean taxa, the apparent origin of Puya generally from the southern Andes, and the presence in the southern Andes and nearby Pacific lowlands of several members of basal grade or clade of bromelioids, including Fascicularia, Greigia, and Ochagavia (see Results and Schulte et al., 2005). Subsequent diversification of Bromelioideae entailed dispersal of Bromelia and Ananas throughout much of lowland South and Central America, with colonization of the Brazilian Shield independently by Bromelia and by the 
ancestor(s) of Fernseea (see Schulte et al., 2005) and the large number of genera sister to it (Fig. 8). This last lineage-the Brazilian Shield clade_-apparently arose 9.1 Ma (Fig. 8).

We propose that the origin of the bromelioid epiphytic clade in and around the Serra do Mar roughly 5.5 Ma corresponds to three key events, involving (1) uplift of the Serra do Mar mainly during Pliocene-Pleistocene times (Almeida, 1976; Amorim and Pires, 1996), (2) uplift of the central Andean Altiplano toward the end of the Miocene (Garzione et al., 2008), and (3) origin of a cooler, rainier climate in the Serra do Mar/Atlantic rain-forest region predicted to result from the impact of central Andean uplift on wind circulation, with increased advection of moisture from the Atlantic as winds from the Pacific were blocked (Ehlers and Poulsen, 2009). The climate models of Ehlers and Poulsen (2009) assume all other factors remained constant as the height of the Andes varied, so the actual uplift of the Serra do Mar mainly from the Pliocene to the present most likely would have caused the observed onset there of cooler, rainier, more humid conditions congenial to epiphytes starting around 5.6 Ma (Vasconcelos et al., 1992; Grazziotin et al., 2006), corresponding nearly exactly with the calculated time of origin of the bromelioid epiphytic clade. Today the Atlantic forest region, including highly diverse but largely destroyed Atlantic rain forests and cloud forests, sandy coastal restingas, mangroves, campos de altitude, and granitic outcrops of the Serra do Mar and Serra da Mantiqueira and adjacent coastal plains, are the wettest part of eastern South America, and the montane habitats are the coolest (Safford, 1999). The Serra do Mar and Serra da Mantiqueira represent the elevated southeastern rim of the tilted Brazilian Shield, and these "seas of hills" ("mares do morros") between roughly $22^{\circ}$ and $29^{\circ} \mathrm{S}$ intercept heavy rainfall and fog from moisture carried by winds off the tropical south Atlantic, as well as occasional cold fronts spawned in Antarctica. Strong climatic fluctuations occurred in this montane region during the Pleistocene (e.g., Behling and Negrelle, 2001), much as they did in the northern Andes (van der Hammen, 1995).

Most bromelioids that arrived in the Brazilian Shield earlier than the origin of the epiphytic clade, during a drier phase and presumably by gradual, short-distance dispersal from the southern Andean region via a corridor of semiarid habitats, are highly xeromorphic terrestrial taxa (Bromelia, Pseudananas, Ananas, Cryptanthus, Orthophytum). Fernseea, sister to all other members of the Brazilian Shield clade (Schulte et al., 2009), is restricted to cool, moist, rocky microsites on the lofty Itatiaia Massif (2800 m a.s.1.) in the Serra da Mantiqueira (Medina et al., 2006), a mountain chain inland of the Serra do Mar in the Atlantic forest region and uplifted somewhat earlier (Amorim and Pires, 1996; Modenesi-Gauttieri and Motta de Toledo, 1996). Fernseea may thus have arrived directly from cool, moist habitats in the southern Andes via long-distance seed dispersal. Climatic oscillations throughout the Pleistocene included rainier phases during which the isolation of Amazonian and Atlantic rain forests from each other by semiarid vegetation may have been greatly reduced (Auler and Smart, 2001; Wang et al., 2004), which would have promoted the later dispersal of bromelioids from the Serra do Mar to other areas, and dispersal of other bromeliads (e.g., Guzmania, Tillandsia, Vriesea) into the Serra do Mar.

Dispersal of ancestral bromelioids from the southern Andes to the mountains of southeastern Brazil is consistent with the proposal of Schulte et al. (2005), although we envision at least two colonizations, involving a long-distance, mesic "high road" for Fernseea (as argued by Schulte et al., 2005) and a gradual, semiarid "low road" for the remaining taxa, with subsequent evolution of mesomorphic epiphytic taxa in the Atlantic forest region. The defining disjunction of Bromelioideae between the southern Andes and the Atlantic forest region is similar that seen in several other plant groups, including Araucaria, Cordyline, Drimys, Fuchsia sect. Quelusia, and Griselinia (Zinmeister, 1987; Berry, 1989; Katinas et al., 1999; Berry et al., 2004). Most of these cases, however, probably involved a mesic "high road" to the Brazilian Shield, either via long-distance dispersal or (more likely in these ancient groups) as relicts of more widespread mesic temperate forests in the southern hemisphere during the Tertiary. In more recently dispersed groups, gradual spread of mesic-adapted taxa from the Andes to the Brazilian Highlands during glacial cycles of the last few million years is another possibility (Safford, 1999). Although glacial/interglacial cycles had much less amplitude prior to ca. 2.8 Ma (Lisiecki and Raymo, 2005), Antarctic ice sheets are known to have advanced and retreated until at least ca. 4.9 Ma (Naish et al., 2009), so dispersal of bromelioids from the southern Andes to southeastern Brazil during a glacial period cannot be excluded.

The initial diversifications of the tillandsioid and epiphytic tank bromelioid radiations roughly $14.0-8.7 \mathrm{Ma}$ and 5.5 Ma, respectively, associated with independent origins of the tank habit (Givnish et al., 2007), corresponds well with the independently derived dates of origin of diving-beetle lineages endemic to bromeliad tanks ca. $12 \mathrm{Ma}$ in northern South America and ca. $4 \mathrm{Ma}$ in the Serra do Mar region (Balke et al., 2008 and inferences regarding ancestral distributions). In addition, the estimated origin of Bothrops (fer-de-lance) species endemic to Atlantic rain forests ca. 3.8 Ma (Grazziotin et al., 2006) agrees fairly well with our estimate of the origin there of the epiphytic tank bromelioids in wet forests ca. 5.5 Ma.

Pitcairnia feliciana apparently arrived in tropical West Africa via recent long-distance dispersal from South America no earlier than about 9.3 Ma. This accords with Maschalocephalus dinklagei of Rapateaceae also being a product of recent longdistance dispersal, not ancient vicariance via continental drift (Givnish et al., 2000, 2004). Recent colonization might partly explain the lack of African speciation in both groups, but that seems quite unlikely; the bromelioid epiphytic clade spawned nearly 600 species in less than half the time that we estimate Pitcairnia and Maschalocephalus have been in Africa. Historical cycles of aridity (Goldblatt, 1993; Querouil et al., 2003) probably played a more important role, given that neither Rapateaceae nor Pitcairnia are especially drought-tolerant (Givnish et al., 2004, 2007) and that neither clade contains species with fully developed CAM photosynthesis (Crayn et al., 2001, 2004).

The African endemics of these families occupy nearly adjacent ranges: Mascalocephalus in savannas and forests on wet sand from Sierra Leone to Côte d'Ivoire; Pitcairnia feliciana on sandstone outcrops of the Fouta Djalon massif in Guinea a few hundred kilometers to the northwest (Porembski and Barthlott, 1999; Givnish et al., 2000, 2004). The Guinean Mountains maintained a wet climate during the Pleistocene, serving as a refugium for wet-climate taxa (Jahns et al., 1998; Dupont et al., 2000). Both Rapateaceae and Bromeliaceae are also likely to have been favored by infertile soils, given their origin and continued abundance in the Guayana Shield. Therefore, early vicariance of habitat - through rafting of sandstone deposits to either side of the Atlantic-followed, much later, by long- 
distance dispersal appears to have caused the disjunct distributions of rapateads and bromeliads (Givnish et al., 2004). There are roughly 10 other angiosperm families with amphiatlantic distributions (Thorne, 1972, 1973); the use of fossil-calibrated molecular clocks shows that recent, long-distance dispersal probably accounts for this pattern in Melastomaceae (Renner and Meyer, 2001) and Vochysiaceae (Sytsma et al., 2004) as well, with trans-Atlantic dispersal having occurred in these families well before it did in bromeliads or rapateads.

It might be argued that, even with a sample of 90 bromeliad stratified across all subfamilies and most genera, that it would be premature to reconstruct biogeographic (or, in other contexts, morphological or ecological) ancestral character states, given that less than $3 \%$ of all extant bromeliad species are included in our analysis. We disagree. First, the full range of geographic distributions have been considered for all genera included, and less than $3 \%$ of bromeliad species have been excluded in that process. More importantly, a detailed study of biogeographic and morphological variation with Bromelioideae, based on a substantially denser sampling of taxa (150 species, ca. $17.5 \%$ of all bromelioids), showed that both groups of characters were phylogenetically highly conserved (Sass and Specht, 2010). Such conservatism supports the placeholder approach used here.

What morphological and physiological traits adapted bromeliads for life outside the Guayana Shield? How frequently did they arise? Were they acquired sequentially or nearly simultaneously? To what extent is variation among the eight bromeliad subfamilies in species number and diversification rate correlated with these traits and the environments invaded by those subfamilies? What factors make the Tillandsioideae and Bromelioideae, with 40 and $27 \%$ of all bromeliad species, respectively, especially diverse? Each of these questions will be addressed in a companion paper, building on the phylogenetic, chronological, and biogeographic reconstructions presented here and new reconstructions of the ancestral states of various morphological, physiological, and ecological characters.

\section{LITERATURE CITED}

Acevedo, M., D. Wake, C. Vasquez, and S. Rovito. 2008. Dendrotriton cuchumatanus. IUCN Red List of threatened species (v. 2009.2). Website http://www.iucnredlist.org [accessed 29 November 2009].

Almeida, F. F. M. 1976. The system of continental rifts bordering the Santos basin, Brazil. Anais da Academia Brasileira de Ciencias 48: $15-26$.

Amorim, D. DE D., AND M. R. S. Pires. 1996. Neotropical biogeography and a method for maximum biodiversity estimation. In C. E. M. Bicudo and N. A. Menezes [eds.], Biodiversity in Brazil: A first approach, 183-291. CNPq, São Paulo, Brazil.

Antonelli, A., J. A. A. Nylander, C. Persson, and I. Sanmartin. 2009. Tracing the impact of the Andean uplift on Neotropical plant evolution. Proceedings of the National Academy of Sciences, USA 106: 9749-9754.

Auler, A. S., And P. L. Smart. 2001. Late Quaternary paleoclimate in semiarid northeastern Brazil from U-series dating of travertine and water-table speleothems. Quaternary Research 55: 159-167.

Balke, M., J. Gómez-Zurita, I. Ribera, A. Viloria, A. Zillikens, J. Steiner, M. Garcia, ET AL. 2008. Ancient associations of aquatic beetles and tank bromeliads in the Neotropical forest canopy. Proceedings of the National Academy of Sciences, USA 105: 6356-6361.

Barfuss, M. H. J., R. Samuel, W. Till, and T. F. Stuessy. 2005. Phylogenetic relationships in subfamily Tillandsioideae (Bromeliaceae) based on DNA sequence data from seven plastid regions. American Journal of Botany 92: 337-351.
Baum, D. A., K. J. Sytsma, And P. C. Hoch. 1994. A phylogenetic analysis of Epilobium (Onagraceae) based on nuclear ribosomal DNA sequences. Systematic Botany 19: 363-388.

BeAman, R. S., AND W. S. JudD. 1996. Systematics of Tillandsia subgenus Pseudalcantarea (Bromeliaceae). Brittonia 48: 1-19.

Behling, H., AND R. R. B. Negrelle. 2001. Tropical rain forest and climate dynamics of the Atlantic lowland, southern Brazil, during the late Quaternary. Quaternary Research 56: 383-389.

BENZING, D. H. 1970. An investigation of 2 bromeliad mymecophytesTillandsia butzii Mez, T. caput-medusae Morren, and their ants. Bulletin of the Torrey Botanical Club 97: 109-115.

Benzing, D. H. 1980. Biology of the bromeliads. Mad River Press, Eureka, California, USA.

BenZING, D. H. 1990. Vascular epiphytes: General biology and associated biota. Cambridge University Press, New York, New York, USA.

Benzing, D. H. 2000. Bromeliaceae: Profile of an adaptive radiation. Cambridge University Press, New York, New York, USA.

Benzing, D. H., T. J. Givnish, AND D. L. Bermudez. 1985. Absorptive trichomes in Brocchinia reducta (Bromeliaceae) and their evolutionary significance. Systematic Botany 10: 81-91.

Berry, P. E. 1989. A systematic revision of Fuchsia sect. Quelusia (Onagraceae). Annals of the Missouri Botanical Garden 76: 532-584.

Berry, P. E., W. J. Hahn, K. J. Sytsma, J. C. Hall, and A. Mast. 2004 Phylogenetic relationships and bogeography of Fuchsia (Onagraceae) based on noncoding nuclear and chloroplast DNA data. American Journal of Botany 91: 601-614.

BleiweIss, R. 1998. Tempo and mode of hummingbird evolution. Biological Journal of the Linnean Society. 65: 63-76.

Bremer, B., K. Bremer, N. Heidari, P. Erixon, R. G. Olmstead, A. A. Anderberg, M. Källersjo, and E. Barkhordarian. 2002 Phylogenetics of asterids based on 3 coding and 3 non-coding chloroplast DNA markers and the utility of non-coding DNA at higher taxonomic levels. Molecular Phylogenetics and Evolution 24: 274-301.

BREMER, K. 2000. Early Cretaceous lineages of monocot flowering plants. Proceedings of the National Academy of Sciences, USA 97: 4707-4711.

Bremer, K. 2002. Gondwanan evolution of the grass alliance of families (Poales). Evolution 56: 1374-1387.

Butcher, D. 2008. Key to the genera of the Bromeliaceae. Website http://fcbs.org/articles/generakey.htm [accessed 17 April 2011].

Buzato, S., M. Sazima, and I. Sazima. 2000. Hummingbird-pollinated floras at three Atlantic forest sites. Biotropica 32: S824-S841.

Chase, M. W., M. F. Fay, D. S. Devey, O. Maurin, N. Rønsted, T. J. Davies, Y. Pillon, ET AL. 2006. Multigene analyses of monocot relationships: A summary. Aliso 22: 63-75.

Clayton, J. W., P. S. Soltis, and D. E. Soltis. 2009. Experimental design in caecilian systematics: Phylogenetic information of mitochondrial genomes and nuclear rag1. Systematic Biology 58: 395-410.

Coltorti, M., And C. D. Ollier. 2000. Geomorphic and tectonic evolution of the Ecuadorian Andes. Geomorphology 32: 1-19.

Crayn, D. M., R. G. Terry, J. A. C. Smith, and K. Winter. 2000. Molecular systematic investigations in Pitcairnioideae (Bromeliaceae) as a basis for understanding the evolution of crassulacean acid metabolism (CAM). 2000. In K. L. Wilson and D. A. Morrison [eds.], Monocots: Systematics and evolution, 569-579. CSIRO, Melbourne, Australia.

Crayn, D. M., J. A. C. Smith, and K. Winter. 2001. Carbon-isotope ratios and photosynthetic pathways in the Neotropical family Rapateaceae. Plant Biology 3: 569-576.

Crayn, D. M., K. Winter, And J. A. C. Smith. 2004. Multiple origins of crassulacean acid metabolism and the epiphytic habit in the Neotropical family Bromeliaceae. Proceedings of the National Academy of Sciences, USA 101: 3703-3708.

Darlu, P., AND G. LeCointre. 2002. When does the incongruence length difference test fail? Molecular Biology and Evolution 19: 432-437.

de Faria, A. P. G., T. Wendt, and G. K. Brown. 2004. Cladistic relationships of Aechmea (Bromeliaceae, Bromelioideae) and allied genera. Annals of the Missouri Botanical Garden 91: 303-319. 
DoyLE, J. J. 1992. Gene trees and species trees-Molecular systematics as one-character taxonomy. Systematic Botany 17: 144-163.

Dupont, L. M., S. Jahns, F. Marret, AND S. Ning. 2000. Vegetation change in equatorial west Africa: Time-slices for the last $150 \mathrm{ka}$ Palaeogeography, Palaeoclimatology, Palaeoecology 155: 95-122.

Ehlers, T. A., AND C. J. Poulsen. 2009. Influence of Andean uplift on climate and paleoaltimetry estimates. Earth and Planetary Science Letters 281: 238-248.

Farris, J. S., V. A. Albert, M. Källersjö, D. Lipscomb, and A. G. KLUGE. 1996. Parsimony jackknifing outperforms neighbor-joining. Cladistics 12: 99-125.

Farris, J. S., M. KällersJö, A. G. Kluge, and C. Bult. 1994. Testing significance of incongruence. Cladistics 5: 417-419.

Felsenstein, J. 1985. Confidence limits on phylogenies: An approach using the bootstrap. Evolution 39: 783-791.

Felsenstein, J. 1993. PHYLIP (Phylogeny Inference Package) version 3.5c [computer program]. Distributed by the author, Department of Genetics, University of Washington, Seattle, Washington, USA.

Figueiredo, J., C. Hoorn, P. van der Ven, AND E. Soares. 2009. Late Miocene onset of the Amazon River and the Amazon deep-sea fan: Evidence from the Foz do Amazonas Basin. Geology 37: 619-622.

FISH, D. 1976. Structure and composition of the aquatic invertebrate community inhabiting epiphytic bromeliads in south Florida and the discovery of an insectivorous bromeliad. Ph.D. dissertation, University of Florida, Gainesville, Florida, USA.

Frank, J. H., and G. F. O'Meara. 1984. The bromeliad Catopsis berteroniana traps terrestrial arthropods but harbors Wyeomyia larvae (Diptera: Culicidae). Florida Entomologist 67: 418-424.

Garzione, C. N., G. D. Hoke, J. C. Liarkin, S. Withers, B. MacFadden, J. Eiler, P. Ghosh, and A. Mulch. 2008. Rise of the Andes. Science 320: 1304-1307

Gaut, B. S., L. G. Clark, J. F. Wendel, and S. V. Muse. 1997. Comparisons of the molecular evolutionary process at $r b c \mathrm{~L}$ and $\mathrm{n} d h \mathrm{~F}$ in the grass family (Poaceae). Molecular Biology and Evolution 14: 769-777.

Gaut, B. S., S. V. Muse, W. D. Clark, and M. T. Clegg. 1992. Relative rates of nucleotide substitution at the $r b c L$ locus in monocotyledonous plants. Journal of Molecular Evolution 35: 292-303.

Gilmartin, A. J., AND G. K. Brown. 1987. Bromeliales, related monocots, and resolution of relationships among Bromeliaceae subfamilies. Systematic Botany 12: 493-500.

Givnish, T. J., M. Ames, J. R. McNeal, M. R. McKain, P. R. Steele, C. W. DEPAmphilis, S. W. Graham, ET AL. 2010. Assembling the tree of the monocotyledons: Plastome sequence phylogeny and evolution of Poales. Annals of the Missouri Botanical Garden 97: 584-616.

Givnish, T. J., E. L. Burkhardt, R. E. Happel, and J. W. Weintraub. 1984. Carnivory in the bromeliad Brocchinia reducta, with a cost/ benefit model for the general restriction of carnivorous plants to sunny, moist, nutrient-poor habitats. American Naturalist 124: 479-497.

Givnish, T. J., T. M. Evans, J. C. Pires, M. L. Zjhra, T. B. Patterson, P. E. Berry, and K. J. Sytsma. 2000. Molecular evolution, adaptive radiation, and geographic diversification in the amphiatlantic family Rapateaceae: Evidence from $n d h F$ sequences and morphology. Evolution 54: 1915-1937.

Givnish, T. J., K. C. Millam, T. M. Evans, J. C. Hall, J. C. Pires, P. E. BerRy, AND K. J. Sytsma. 2004. Ancient vicariance or recent longdistance dispersal? Inferences about phylogeny and South AmericanAfrican disjunction in Rapateaceae and Bromeliaceae based on $n d h F$ sequence data. International Journal of Plant Sciences 165: S35-S54.

Givnish, T. J., K. C. Millam, P. E. Berry, and K. J. Sytsma. 2007. Phylogeny, adaptive radiation, and historical biogeography of Bromeliaceae inferred from $n d h \mathrm{~F}$ sequence data. In J. T. Columbus, E. A. Friar, J. M. Porter, L. M. Prince, and M. G. Simpson [eds.], Monocots: Comparative biology and evolution-Poales, 3-26. Rancho Santa Ana Botanic Garden, Claremont, California, USA.

Givnish, T. J., K. C. Millam, T. T. Theim, A. R. Mast, T. B. Patterson, A. L. HIPP, J. M. HensS, ET AL. 2009. Origin, adaptive radiation, and diversification of the Hawaiian lobeliads (Asterales: Campanulaceae). Proceedings of the British Society, B, Biological Sciences 276: 407-416.
Givnish, T. J., J. C. Pires, S. W. Graham, M. A. McPherson, L. M. Prince, T. B. PAtTERSON, H. S. RAI, ET AL. 2005. Repeated evolution of net venation and fleshy fruits among monocots in shaded habitats confirms a priori predictions: Evidence from an $n d h F$ phylogeny. Proceedings of the British Society, B, Biological Sciences 272: 1481-1490.

Givnish, T. J., AND K. J. SyTsma. 1997. Consistency, characters, and the likelihood of correct phylogenetic inference. Molecular Phylogenetics and Evolution 7: 320-330.

Givnish, T. J., K. J. Sytsma, J. F. Smith, W. J. Hahn, D. H. Benzing, AND E. M. BurKhardT. 1997. Molecular evolution and adaptive radiation in Brocchinia (Bromeliaceae: Pitcairnioideae) atop tepuis of the Guayana Shield. In T. J. Givnish and K. J. Sytsma [eds.], Molecular evolution and adaptive radiation, 259-311. Cambridge University Press, New York, New York, USA.

Goldblatt, P. 1993. Biological relationships between Africa and South America. Yale University Press, New Haven, Connecticut, USA.

Goloboff, P. 1999. Analyzing large data sets in reasonable times: Solutions for composite optima. Cladistics 15: 415-428.

Gonçalves, C.N.,ANDC.F.DEAzEvêdo-Gonçalves. 2009. Anewhybrid bromeliad from southernmost Brazil, Tillandsia $\times$ baptistana. Novon 19: 353-356.

GonsisKa, P. A. 2010. Phylogeny and ecology of Catopsis (Bromeliaceae: Tillandsioideae). Ph.D. dissertation, University of Wisconsin, Madison, Wisconsin, USA.

Graham, S. W., J. M. Zgurski, M. A. McPherson, D. M. Cherniawsky, J. M. SaArela, E. S. C. Horne, S. Y. Smith, et Al. 2006. Robust inference of monocot deep phylogeny using an expanded multigene plastid data set. Aliso 22: 3-20.

Graybeal, A. 1998. Is it better to add taxa or characters to a difficult phylogenetic problem? Systematic Biology 47: 9-17.

Grazziotin, F. G., M. Monzel, S. Echeverrigaray, and S. L. BonATTO. 2006. Phylogeography of the Bothrops jararaca complex (Serpentes: Viperidae): Past fragmentation and island colonization in the Brazilian Atlantic Forest. Molecular Ecology 15: 3969-3982.

GREGORY-WODZICKI, K. M. 2000. Uplift history of the central and northern Andes: A review. Geological Society of America Bulletin 112: $1091-1105$

Guindon, S., AND O. Gascuel. 2003. A simple, fast, and accurate algorithm to estimate large phylogenies by maximum likelihood. Systematic Biology 52: 696-704.

Harms, H. 1930. Bromeliaceae. In A. Engler and K. Prantl [eds.], Die natürlichen Pflanzenfamilien, vol. 15a, 65-159. W. Engelmann, Leipzig, Germany.

Harris, A. J., AND Q.-Y. XIANG. 2009. Estimating ancestral distributions of lineages with uncertain sister groups: A statistical approach to dispersal-vicariance analysis and a case using Aesculus L. (Sapindaceae) including fossils. Journal of Systematics and Evolution 47: 349-368.

Hendy, M. D., And D. Penny. 1989. A framework for the quantitative study of evolutionary trees. Systematic Zoology 38: 296-309.

Hesse, M., AND R. Zetter. 2007. The fossil pollen record of Araceae. Plant Systematics and Evolution 263: 93-115.

HiLlis, D. M. 1996. Inferring complex phylogenies. Nature 383: 130-131.

Holst, B. K. 1997. Bromeliaceae. In P. E. Berry, J. A. Steyermark, and K. Yatskievych [eds.], Flora of the Alta Guayana, vol. 2, 548-676. Missouri Botanical Garden Press, St. Louis, Missouri, USA.

Hoorn, C. 1994. An environmental reconstruction of the palaeo-Amazon river system (middle-late Miocene, NW Amazonia. Palaeogeography, Palaeoclimatology, Palaeoecology 112: 187-238.

Hoorn, C., J. Guerrero, G. A. Sarmiento, and M. A. Lorente. 1995. Andean tectonics as a cause for changing drainage patterns in Miocene northern South America. Geology 23: 237-240.

Hoorn, C., F. P. Wesselingh, H. ter Steege, M. A. Bermudez, A. Mora, J. SevinK, I. Sanmartin, ET AL. 2010. Amazonia through time: Andean uplift, climate change, landscape evolution, and biodiversity. Science 330: 927-931.

Horres, R., K. Schulte, and G. Zizka. 2007. Systematics of Bromelioideae: Evidence from molecular and anatomical studies. Aliso 23: 27-43. 
Horres, R., G. Zizka, G. KAHL, AND K. Weising. 2000. Molecular phylogenetics of Bromeliaceae: Evidence from $\operatorname{trnL}$ (UAA) intron sequences of the chloroplast genome. Plant Biology 2: 306-315.

IbARAKI, M. 1997. Closing of the Central American Seaway and Neogene coastal uplwelling along the Pacific coast of South America. Tectonophysics 281: 99-104.

Jabaily, R. S. 2009. Phylogeny and evolution of Puya (Bromeliaceae). Ph.D. dissertation, University of Wisconsin, Madison, Wisconsin, USA.

Jabaily, R. S., and K. J. Sytsma. 2010. Phylogenetics of Puya (Bromeliaceae): Placement, major lineages, and evolution of Chilean species. American Journal of Botany 97: 337-356.

Jahns, S., M. Huls, AND M. SARnTHEIn. 1998. Vegetation and climate history of west equatorial Africa based on a marine pollen record off Liberia (site GIK 16776) covering the last 400,000 yers. Review of Palaeobotany and Palynology 102: 277-288.

JANSSEN, T., AND K. BREMER. 2004. The age of major monocot groups inferred from $800+r b c L$ sequences. Botanical Journal of the Linnean Society 146: 385-398.

Katinas, L., J. J. Morrone, AND J. V. CRisci. 1999. Track analysis reveals the composite nature of the Andean biota. Australian Journal of Botany 47: 111-130.

Kessler, M. 2001. Patterns of diversity and range size of selected plant groups along an elevational transect in the Bolivian Andes. Biodiversity and Conservation 10: 1897-1921.

Kirby, M. X., D. S. Jones, and B. J. MacFadden. 2008. Lower Miocene stratigraphy along the Panama Canal and its bearing on the Cental American peninsula. PLoS ONE 3: e2791.

Kodandaramaiah, U. 2010. Use of dispersal-vicariance analysis in biogeography-A critique. Journal of Biogeography 37: 3-11.

Krömer, T., M. Kessler, S. R. Gradstein, AND A. ACeby. 2005. Diversity patterns of vascular epiphytes along an elevational gradient in the Andes. Journal of Biogeography 32: 1799-1809.

Krömer, T., M. Kessler, AND S. K. Herzog. 2006. Distribution and flowering ecology of bromeliads along two climatically contrasting elevational transects in the Bolivian Andes. Biotropica 38: 183-195.

Langley, C. H., AND W. Fitch. 1974. An estimation of the constancy of the rate of molecular evolution. Journal of Molecular Evolution 3: 161-177.

Leebens-Mack, J. H., L. A. Raubeson, L. Cui, J. V. Kuehl, M. H. Fourcade, T. W. Chumley, J. L. Boore, R. K. Jansen, and C. W. DEPAMPHILIS. 2005. Identifying the basal angiosperm node in chloroplast genome phylogenies: Sampling one's way out of the Felsenstein zone. Molecular Biology and Evolution 22: 1948-1963.

Lemé, E. M. C. 1993. Bromeliads in the Brazilian wilderness. Marigo Communicacao, Rio de Janeiro, Brazil.

Lemé, E., G. K. Brown, D. Dilcher, M. Bernardes de Oliviera, J. Siqueira, AND A. SAles. 2005. Protananaceae, a new fossil monocot family from the Lower Cretaceous, Santana Formation, northeastern Brazil. In Proceedings of Botany 2005, Austin, Texas, USA. Website http://www.2005.botanyconference.org/engine/search/index. php? func=detail\&aid=666 [abstract]. Botanical Society of America, St. Louis, Missouri, USA.

Linares-Palomino,R.,V.Cardona,E.I.Hennig,I.Hensen,D.Hoffmann, J. Lendzion, D. Soto, S. K. Herzog, And M. Kessler. 2009. Nonwoody life-form contribution to vascular plant species richness in a tropical American forest. Plant Ecology 201: 87-99.

Linares-Palomino, R., AND M. Kessler. 2009. The role of dispersal ability, climate and spatial separation in shaping biogeographical patterns in seasonally dry Andean forests of Bolivia. Journal of Biogeography 36: 280-290.

LisiecKi, L. E., AND M. E. Raymo. 2005. A Pliocene-Pleistocene stack of 57 globally distributed benthic $\delta^{18} \mathrm{O}$ records. Paleoceanography 20: PA1003.

Luther, H. 1993. An unusual night-flowering Guzmania from southern Ecuador. Journal of the Bromeliad Society 43: 195-197.

Luther, H. 2008. An alphabetical list of bromeliad binomials, 11th ed. Bromeliad Society International, Lutz, Florida, USA. Available at website http://www.selby.org/research/papers/alphabetical-list-bromeliad-binomials, Marie Selby Botanical Gardens, Sarasota, Florida, USA.
MadDison, D. R., AND W. P. MadDison. 2005. MacClade 4: Analysis of phylogeny and character evolution, version 4.08. Sinauer, Sunderland, Massachusetts, USA.

McWilliams, E. L. 1974. Evolutionary ecology. In L. B. Smith and R. J. Downs, Pitcairnioideae (Bromeliaceae), 40-55. Flora Neotropica Monongraph 14, part 1. Hafner Press, New York, New York, USA.

Medina, B. M. O., K. T. Ribeiro, and F. R. Scarano. 2006. Plant-plant and plant-topography interactions on a rock outcrop at high altitude in southeastern Brazil. Biotropica 38: 27-34.

Mez, C. 1904. Physiologische Bromeliaceen-Studien I. Die WasserÖkonomie der extrem atmosphärischen Tillandsien. Jahrbücher für wissenschaftliche Botanik 40: 157-229.

Miller, M. A., M. T. Holder, R. Vos, P. E. Midford, T. Liebowitz, L. Chan, P. Hoover, and T. Warnow. 2010. The CIPRES Portals CIPRES. 2009-08-04. Website http://www.phylo.org/sub_sections/portal, archived by WebCite(r) at http://www.webcitation. org/5imQUeQa [Accessed 10 September 2010].

Modenesi-Gauttieri, M. C., and M. C. Motta de Toledo. 1996. Weathering and the formation of hillslope deposits in the tropical highlands of Itatiaia-southeastern Brazil. Catena 27: 81-103.

Naish, T., R. Powell, R. Levy, G. Wilson, R. Scherer, F. TAlarico, L. KrisseK, ET AL. 2009. Obliquity-paced Pliocene West Antarctic ice sheet oscillations. Nature 458: 322-329.

Nixon, K. C. 1999. The Parsimony Ratchet, a new method for rapid parsimony analysis. Cladistics 15: 407-414.

Nylander, J. A. A., U. Olsson, P. Alström, and I. Sanmartín. 2008. Accounting for phylogenetic uncertainty in biogeography: A Bayesian approach to dispersal-vicariance analysis of the thrushes (Aves: Turdus). Systematic Biology 57: 257-268.

Olmstead, R. G., C. W. dePamphilis, A. D. Wolfe, N. D. Young, W. J. Elisens, and P. A. Reeves. 2001. Disintegration of the Scrophulariaceae. American Journal of Botany 88: 348-361.

Olmstead, R. G., R. K. Jansen, K. J. Kim, and S. J. Wagstaff. 2000. The phylogenyof the Asteridae s. 1. based on chloroplst $n d h F$ sequences. Molecular Phylogenetics and Evolution 16: 96-112 n.

PAGEL, M. 1999. The maximum likelihood approach to reconstructing ancestral character states of discrete characters on phylogenies. Systematic Biology 48: 612-622.

Pagel, M., And A. Meade. 2004. A phylogenetic mixture model for detecting pattern-heterogeneity in gene sequence or character-state data. Systematic Biology 53: 673-684.

Pagel, M., And A. Meade. 2007. BayesTraits v.1.0. Computer program available at website http://www.evolution.rdg.ac.uk.

Pagel, M., And A. Meade. 2008. Modelling heterotachy in phylogenetic inference by reversible-jump Markov chain Monte Carlo. Philosophical Transactions of the Royal Society, B, Biological Sciences 363: 3955-3964.

Pagel, M., A. Meade, and D. Barker. 2004. Bayesian estimation of ancestral character states on phylogenies. Systematic Biology 53: 673-684.

Paoletti, M. G., R. A. J. Taylor, B. R. Stinner, D. H. Stinner, and D. H. BENZING. 1991. Diversity of soil fauna in the canopy and forest floor of a Venezuelan cloud forest. Journal of Tropical Ecology 7: 373-383.

Pires, J. C., AND K. J. Sytsma. 2002. A phylogenetic evaluation of a biosystematic framework: Brodiaea and related petaloid monocots (Themidaceae). American Journal of Botany 89: 1342-1359.

Pittendrigh, C. S. 1948. The bromeliad-Anopheles-malaria complex in Trinidad. I. The bromeliad flora. Evolution 2: 58-89.

PorembSki, S., ANd W. Barthlott. 1999. Pitcairnia feliciana: The only indigenous African bromeliad. Harvard Papers in Botany 4: 175-184.

PosadA, D. 2008. jModelTest: Phylogenetic model averaging. Molecular Biology and Evolution 25: 1253-1256.

Posada, D., AND T. R. BuckLey. 2004. Model selection and model averaging in phylogenetics: Advantages of the AIC and Bayesian approaches over likelihood ratio tests. Systematic Biology 53: 793-808.

Potter, P. E. 1997. The Mesozoic and Cenozoic paleodrainage of South America: A natural history. Journal of South American Earth Sciences 10: 331-344.

Querouil, S., E. Verhey, M. Dillon, and M. Colyn. 2003. Patterns of diversification in two African forest shrews: Sylvisorex johnstoni and 
Sylvisorex ollula (Soricidae, Insectivora) in relation to paleo-environmental changes. Molecular Phylogenetics and Evolution 28: 24-37.

Ree, R. H., B. R. Moore, C. O. Webb, and M. J. Donoghue. 2005. A likelihood framework for inferring the evolution of geographic range on phylogenetic trees. Evolution 59: 2299-2311.

ReE, R. H., AND S. A. Smith. 2008. Maximum likelihood inference of geographic range evolution by dispersal, local extinction, and cladogenesis. Systematic Biology 57: 4-14.

Renner, S. S., ANd K. Meyer. 2001. Melastomeae come full circle: Biogeographic reconstruction and molecular clock dating. Evolution 55: 1315-1324.

Rex, M., K. Patzolt, K. Schulte, G. Zizka, R. Vásquez, P. L. Ibisch, AND K. WeIsING. 2007. AFLP analysis of genetic relationships in the genus Fosterella L. B. Smith (Pitcairnioideae, Bromeliaceae). Genome 50: 90-105.

RichaRdSON, B. A. 1999. The bromeliad microcosm and the assessment of faunal diversity in a Neotropical forest. Biotropica 31: 321-336.

Romero, G. Q., P. Mazzafera, J. Vasconcellos-Neto, and P. C. O. Trivelin. 2006. Bromeliad-living spiders improve host plant nutrition and growth. Ecology 87: 803-808.

RoNQUisT, F. 1996. DIVA, version 1.1. Computer program and manual available by anonymous FTP at ftp.uu.se or ftp.systbot.uu.se, Uppsala University, Uppsala, Sweden..

RonQuist, F. 1997. Dispersal-vicariance analysis: A new approach to the quantification of historical biogeography. Systematic Biology 46: 195-203.

Ronquist, F., AND J. P. HuelsenbeCK. 2003. MrBayes 3: Bayesian phylogenetic inference under mixed models. Bioinformatics 19: 1572-1574.

SAFFord, H. D. 1999. Brazilian páramos I. An introduction to the physical environment and vegetation of the campos de altitude. Journal of Biogeography 26: 693-712.

SANDERSON, M. J. 2002. Estimating absolute rates of molecular evolution and divergence times: A penalized likelihood approach. Molecular Biology and Evolution 19: 101-109.

SANDERSON, M. J. 2004. r8s, version 1.70, User's manual [online]. Available at website http://loco.biosci.arizona.edu/r8s/r8s1.7.manual.pdf.

Sass, C., and C. D. Specht. 2010. Phylogenetic estimation of the core bromelioids with an emphasis on the genus Aechmea. Molecular Phylogenetics and Evolution 55: 559-571.

Savolainen, V., M. W. Chase, S. B. Ноot, C. M. Morton, D. E. Soltis, C. BAYER, M. F. FAY, ET AL. 2000. Phylogenetics of flowering plants based upon a combined analysis of plastid $a t p B$ and $r b c L$ gene sequences. Systematic Biology 49: 306-362.

SCHIMPER, A. F. W. 1888. Die epiphytische Vegetation Amerikas. Botanische Mitteilungen aus den Tropen, Heft 2. Gustave Fischer Verlag, Jena, Germany.

Schulte, K., M. H. J. Barfuss, And G. Zizka. 2009. Phylogeny of Bromelioideae (Bromeliaceae) inferred from nuclear and plastid DNA loci reveals the evolution of the tank habit within the subfamily. Molecular Phylogenetics and Evolution 51: 327-339.

Schulte, K., R. Horres, AND G. ZizKa. 2005. Molecular phylogeny of Bromelioideae and its implications on biogeography and the evolution of CAM in the family. Senckenbergiana Biologica 85: 1-13.

Schulte, K., AND G. Zizka. 2008. Multi locus plastid phylogeny of Bromelioideae (Bromeliaceae) and the taxonomic utility of petal appendages and pollen characters. Candollea 63: 209-225.

Shaw, J., E. B. Lickey, E. E. Schilling, and R. L. Small. 2007. Comparison of whole chloroplast genome sequences to choose noncoding regions for phylogenetic studies in angiosperms: The tortoise and the hare III. American Journal of Botany 94: 275-288.

Sikes, D. S., AND P. O. Lewis. 2001. Software manual for PAUPRat: A tool to implement Parsimony Ratchet searches using PAUP*. Website http://users.iab.uaf.edu/ derek_sikes/software2.htm [Accessed 07 April 2011].

SILlETT, T. S. 1994. Foraging ecology of epiphyte-searching insectivorous birds in Costa Rica. Condor 96: 863-877.

Sмiтн, J. A. C. 1989. Epiphytic bromeliads. In U. Lüttge [ed.], Vascular plants as epiphytes: Evolution and ecophysiology, 109-138. SpringerVerlag, Heidelberg, Germany.
Smith, L. B., AND R. J. Downs. 1974. Pitcairnioideae (Bromeliaceae). Flora Neotropica 14: 1-662.

Smith, L. B., AND R. J. Downs. 1977. Tillandsioideae (Bromeliaceae). Flora Neotropica 14: 663-1492.

Smith, L. B., AND R. J. Downs. 1979. Bromelioideae (Bromeliaceae). Flora Neotropica 14: 1493-2142.

Smith, L. B., AND W. J. Kress. 1989. New or restored genera of Bromeliaceae. Phytologia 66: 70-79.

Smith, L. B., AND W. J. Kress. 1990. New genera of Bromeliaceae. Phytologia 69: 271-274.

Smith, L. B., AND W. Till. 1998. Bromeliaceae. In K. Kubitzki [ed.], The families and genera of vascular plants, vol. IV. Alismatanae and Commelinanae (except Gramineae). Springer-Verlag, Berlin, Germany.

Soltis, D. E., P. S. Soltis, M. W. Chase, M. E. Mort, D. C. Albach, M. Zanis, V. Sa volainen, ET AL. 2000. Angiosperm phylogeny inferred from $18 \mathrm{~S}$ rDNA, $r b c L$, and $a t p B$ sequences. Botanical Journal of the Linnean Society 133: 381-461.

Soltis, D. E., P. S. Soltis, M. E. Mort, M. W. Chase, V. Savolainen, S. B. Hoot, and C. B. Morton. 1998. Inferring complex phylogenies using parsimony: An empirical approach using three large DNA data sets for angiopserms. Systematic Biology 47: 32-42.

Stamatakis, A., P. Hoover, and J. Rougemont. 2008. A fast bootstrapping algorithm for the RaxML web-servers. Systematic Biology 57: 758-771.

Stamatakis, A., M. Ott, and T. Ludwig. 2005. RaxML-OMP: An efficient program for phylogenetic inference on SMP's. In Proceedings of the 8th International Conference on Parallel Computing Technologies (PaCT2005). Lecture Notes in Computer Science 3606: 288-302.

Swofford, D. L. 2002. PAUP*: Phylogenetic analysis using parsimony (*and other methods), version 4b10. Sinauer, Sunderland, Massachusetts, USA.

Sytsma, K. J., A. Litt, M. L. Zjhra, J. C. Pires, M. Nepokroeff, E. Conti, J. WALKer, AND P. G. Wilson. 2004. Clades, clocks, and continents: Historical and biogeographical analysis of Myrtaceae, Vochysiaceae, and relatives in the Southern Hemisphere. International Journal of Plant Sciences 165 (4 supplement_): S85-S105.

Terry, R. G., G. K. Brown, and R. G. Olmstead. 1997. Examination of subfamilial phylogeny in Bromeliaceae using comparative sequencing of the plastid locus $n d h \mathrm{~F}$. American Journal of Botany 84: 664-670.

Thorne, R. F. 1972. Major disjunctions in the geographic ranges of seed plants. Quarterly Review of Biology 47: 365-411.

Thorne, R. F. 1973. Floristic relationships between tropical Africa and tropical America. In B. J. Meggers, E. S. Ayensu, and W. D. Duckworth [eds.], Tropical forest ecosystems in Africa and South America: A comparative review, 27-47. Smithsonian Institution Press, Washington, D.C., USA.

Tomlinson, P. B. 1969. Commelinales-Zingiberales. In C. R. Metcalfe [ed.], Anatomy of the monocotyledons, vol. 3, 193-294. Clarendon Press, Oxford, UK.

Tschapka, M., And O. von Helversen. 2007. Phenology, nectar production and visitation behaviour of bats on the flowers of the bromeliad Werauhia gladioliflora in a Costa Rican lowland rain forest. Journal of Tropical Ecology 23: 385-395.

VAN DER HAMmEN, T. 1995. Global change, biodiversity, and conservation of Neotropical montane forests. In S. P. Churchill, H. Balslev, E. Forero, and J. L. Luteyn [eds.], Biodiversity and conservation of Neotropical montane forests, 603-607. New York Botanical Garden, Bronx, New York, USA.

Vasconcelos, P. M., T. A. Becker, P. R. Renne, and G. H. Brimhall. 1992. Age and duration of weathering by ${ }^{40} \mathrm{~K}-{ }^{40} \mathrm{Ar}$ and ${ }^{40} \mathrm{Ar} /{ }^{39} \mathrm{Ar}$ analysis of potassium-manganese oxides. Science 258: 451-455.

Wang, X. F., A. S. Auler, R. L. Edwards, H. Cheng, P. S. Cristalli, P. L. Smart, D. A. Richards, and C. C. Shen. 2004. Wet periods in northeastern Brazil over the past 210 kyr linked to distant climate anomalies. Nature 432: 740-743.

Wendt, T., T. S. Coser, G. Mattalana, and F. A. G. Guilherme. 2008. An apparent lack of prezygotic reproductive isolation among 
42 sympatric species of Bromeliaceae in southern Brazil. Plant Systematics and Evolution 275: 31-41.

Yu, Y., A. J. Harris, AND X. He. 2010. S-DIVA (Statistical DispersalVicariance Analysis): A tool for inferring biogeographic histories. Molecular Phylogenetics and Evolution 56: 848-850.

Zinmeister, W. J. 1987. Cretaceous paleogeography of Antarctica. Palaeogeography, Palaeoclimatology, Palaeoecology 59: 197-206.
Zizka, G., M. Schmidt, K. Schulte, P. Navoa, R. Pinto, and K. König. 2009. Chilean Bromeliaceae: Diversity, distribution and evaluation of conservation status. Biodiversity and Conservation 18: 2449-2471.

ZwICKL, D. J. 2006. Genetic algorithm approaches for the phylogenetic analysis of large biological sequence datasets under the maximum likelihood criterion. Ph.D. dissertation, University of Texas at Austin, Austin, Texas, USA.

APPENDIX 1. Species, vouchers, and GenBank accessions for taxa included in this study. Taxa are grouped by subfamily within Bromeliaceae and by family outside Bromeliaceae. Sequences newly generated for this study begin with HQ or JF. Taxa for which sequences were concatenated in the combined analyses are listed sequentially with an asterisk (*). Sequences for different loci obtained from different accessions of the same species are listed after the corresponding vouchers. Missing sequences are indicated by -.

Taxon; Voucher specimen, Herbarium; GenBank accessions: matK; ndhF; rps16; atpB-rbcL; psbA-trnH; rpl32-trnL; trnL intron/trnL-trnF intergenic spacer

\section{Brocchinioideae}

Brocchinia acuminata L.B.Sm.; SEL 81-1937; AF162228.2; L75859; HQ913837; JF280690; HQ913663; HQ913751; HQ882715. Brocchinia prismatica L.B.Sm.; T. Givnish s.n., WIS; HQ900681; AY438600; HQ913838; JF280691; HQ913664; HQ913752; HQ882716. Brocchinia uiapanensis (Maguire) Givnish; T. Givnish 4200, WIS; HQ900682; AY438599; HQ913839; JF280692; HQ913665; HQ913753; HQ882717.

Lindmanioideae

Connellia cf. nutans L.B.Sm.; P. E. Berry 7741, WIS; -; HQ895740; -; -; -; -; -. Lindmania guianensis (Beer) Mez; W. Till 16018a, WU; AY614019; -; AY614141; AY614385; HQ913695; -; AY614263. Lindmania longipes (L.B.Sm.) L.B.Sm.; T. Givnish s.n., WIS; HQ900683; AY438605; HQ913866; JF280719; HQ913696; HQ913783; HQ882736.

Tillandsioideae

Alcantarea duarteana (L.B.Sm.) J.R.Grant; W. Till 11052, WU; AY614031; -; AY614153; AY614397; HQ913656; HQ913744; -; E. Leme 2891, HB -; HQ895732; -; -; -; -; HQ882711. Catopsis floribunda L.B. Sm.*; MSBG 91-3; AF539963; -; -; -; -; -; -; Catopsis morreniana Mez*; H.B.V. B176/80, WU; -; HQ895739; AY614147; AY614391; HQ913669; HQ913757; HQ882721. Glomeropitcairnia penduliflora (Griseb.) Mez; T Givnish s.n., WIS; -; L75864; -; -; -; -; -; W. Till 12012, WU; AY614030; -; AY614152; AY614396; HQ913686; HQ913774; AY614274. Guzmania monostachia (L.) Rusby ex Mez; SEL 82-225; -; L75865; HQ913859; JF280713; HQ913688; HQ913776; HQ882732; R. Horres H016, FR AY949990; -; -; -; -; -; -. Guzmania rhonhofiana Harms; SEL 801130; -; L75934; -; -; -; -; -; B224/80, WU; AY614064; -; HQ913860 AY614430; HQ913689; HQ913777; AY614308/AY614308. Guzmania roezlii (E.Morren) Mez; H.B.V. 166/96, WU; -; -; HQ913861; JF280714 HQ913690; HQ913778; HQ882733. Mezobromelia hutchisonii (L.B.Sm.) W.Weber \& L.B.Sm.; W. Rauh 40104, HEID; AY614050; HQ895753; AY614172; AY614416; HQ913698; HQ913785; HQ882738. Mezobromelia pleiosticha (Griseb.) Utley \& H.Luther; SEL 81-1986; AF539970; L75891; HQ913868; JF280721; HQ913699; HQ913786; HQ882739. Racinaea ropalocarpa (André) M.A.Spencer \& L.B.Sm.; B256/96, WU; AY614083; -; AY614205; AY614449; HQ913720; HQ913807; AY61437. Tillandsia complanata Benth.; SEL 79-0519; -; L75899; -; -; -; -; -; L. Hromadnik 2137, WU; -; -; HQ913893; -; HQ913725; HQ913812; HQ882757; W. Till 21085a, WU; -; -; -; JF280746; -; -; -. Tillandsia dodsonii L.B.Sm.; Brown 3218, RM; L75879; -; -; -; -; -; W. Rauh 34183, WU; AY614072; -; AY614194; AY614438; HQ913726; -; -; SEL 1973-0004-033; -; -; -; -; -; HQ913813; HQ882758. Tillandsia usneoides (L.) L.; G. Palim s.n., WU; AY614122;-;-;-;-;-; AY614366; M. Barfuss s.n., WU;-;-;AY614243; AY614487; HQ913727; HQ913814; -; ex cult. UW-Madison greenhouses; -; HQ895767; -; -; -; -; -. Tillandsia utriculata L.; G. Brown 3211, RM; -; L75939; -; -; -; -; -; W. Till 17007, WU; AY614090; -; AY614212; AY614456; HQ913728; HQ913815; AY614334. Tillandsia viridiflora (Beer) Baker; H.B.V. B87/80, WU; AY614066; HQ895768; AY614188; AY614432; HQ913729; HQ913816; HQ882759. Vriesea espinosae (L.B.Sm.) Gilmartin; G. Brown 3218, RM; AF539978.2; -; HQ913895; JF280748; HQ913731; HQ913818; HQ882760. Vriesea glutinosa Lindl.; SEL 86-0303; -; L75914; -; -; -; -; -; H.B.V. B444/80, WU; GU475471;
-; HQ913896; JF280749; HQ913732; HQ913819; HQ882761. Vriesea malzinei E.Morren; SEL 78-757; AF162265.2; L75915; HQ913897; JF280750; HQ913733; HQ913820; HQ882762. Werauhia viridiflora (Regel) J.R.Grant; SEL 90-0282; AF539979.2; L75910; HQ913898; JF280751; HQ913734; HQ913821; HQ882763.

Hechtioideae

Hechtia glomerata Zucc.; M. Remmick 139, SEL; AF162245.2; HQ895752; HQ913862; JF280715; HQ913691; HQ913779; HQ882734. Hechtia guatemalensis Mez; SEL 81-1891; -; AY438604; -; -; -; -; -; D. Crayn s.n., SEL; AF162246.2; -; -; -; -; -; -; R. Horres 088, FR; -; -; HQ913863; JF280716; HQ913692; HQ913780; AF188821/DQ084656. Hechtia lindmanioides L.B. Sm.; D. Crayn s.n., SEL; AF162247.2; -; HQ913864; JF280717; HQ913693; HQ913781; HQ882735.

Navioideae

Brewcaria reflexa (L.B.Sm.) B.Holst; Givnish et al., 1997; HQ900680; -; HQ913836; JF280689; HQ913662; HQ913750; HQ882714. Cottendorfia florida Schult. \& Schult.f.; SEL 96-0695; -; AY438602;-; -; -; -; -; E. Leme 3692, HB; AF162230.2; -; -; -; -; -; -; T. Givnish s.n., WIS; -; -; HQ913843; JF280697; HQ913671; HQ913759; HQ882722. Navia phelpsiae L.B.Sm.; MSBG 1986-0523A; AF162249.2; HQ895754; HQ913869; JF280722; HQ913700; HQ913787; HQ882740. Navia saxicola L.B.Sm.; T. Givnish s.n., WIS; HQ900684; AY208983; HQ913870; JF280723; HQ913701; HQ913788; HQ882741. Navia splendens L.B.Sm.; SEL 83-0288; -; L75892; -; -; -; -; -; R. Horres 034, FR; GU475468; -; HQ913871; JF280724; HQ913702; HQ913789; HQ882767. Sequencia serrata (L.B.Sm.) Givnish; T. Givnish s.n., WIS HQ900688; AY438601; HQ913891; JF280744; HQ913723; HQ913810; HQ882756.

Pitcairnioideae

Deuterocohnia glandulosa E.Gross; L. Hromadnik 5167, HEID; EU681893; -; -; -; -; -; -; R. Horres 090, FR; -; HQ895742; HQ913846; JF280700; HQ913674; HQ913762; AF188784/DQ084652. Deuterocohnia longipetala (Baker) Mez; Marnier-Lapostelle s.n.; -; AY208984; -; -; -; -; -; MSBG 075767; AF162231.2; -; HQ913847; JF280701; HQ913675; HQ913763; HQ882724. Deuterocohnia lotteae (Rauh) M.A.Spencer \& L.B.Sm.; MSBG 94-142; AF162232.2; -; -; -; -; -; -; R. Horres 084, FR; -; HQ895743; HQ913848; JF280702; HQ913676; HQ913764; AF188783/DQ084566. Dyckia dawsonii L.B.Sm.; MSBG 1994-0146A; AF162234.2; HQ895744; HQ913849; JF280703; HQ913677; HQ913765; HQ882725. Dyckia ferox Mez; MSBG 1996-0211A; AF162235.2; HQ895745; HQ913850; JF280704; HQ913678; HQ913766; HQ882726. Encholirium irwinii L.B.Sm.; E. Leme 2881, HB; AF162237.2; HQ895748; HQ913854; JF280708; HQ913682; HQ913770; HQ882729. Encholirium scutor (L.B.Smith) Rauh; MSBG 1995-0113A; AF162239.2; HQ895747; HQ913853; JF280707; HQ913681; HQ913769; HQ882728. Fosterella penduliflora (C.H.Wright) L.B.Sm.; SEL 69-1976-12; -; L75863; -; -; -; -; -; R. Horres 086, FR; AY949996; -; HQ913856; JF280710; HQ913684; HQ913772; AF188782/DQ084571. Fosterella petiolata (Mez) L.B.Sm.; MSBG 1995-0007A; AF162242.2; HQ895750; HQ913857; JF280711; HQ913685; HQ913773; HQ882731. Pitcairnia carinata Mez; G. Brown 3173, RM; AF539974.2; L75902; HQ913875; JF280728; HQ913706; HQ913793; HQ882745. Pitcairinia corallina 
Linden \& André; SEL 86-0574; AF162252; AY438608; -; -; -; -; -; $R$. Horres 094, FR; -; -; HQ913876; JF280729; HQ913707; HQ913794; HQ882768. Pitcairinia feliciana (A.Chev.) Harms \& Mildbr.; SEL 980116; -; AY438609; -; -; -; -; -; T. Givnish s.n., WIS; HQ900685; -; HQ913877; JF280730; HQ913708; HQ913795; HQ882746. Pitcairnia heterophylla (Lind1.) Beer; R. Horres 2024, FR; AF162254.2; HQ895757; HQ913878; JF280731; HQ913709; HQ913796; AF188789/DQ084649. Pitcairnia hirtzii H. Luther; SEL 93-294; AF539972; L75901; HQ913879; JF280732; HQ913710; HQ913797; HQ882747. Pitcairnia orchidifolia Mez; MSBG 1994-0036A; AF162255.2; -; HQ913880; JF280733; HQ913711; HQ913798; HQ882748. Pitcairnia poortmanii André; MSBG 1991-0018A; AF539975.1; -; HQ913881; JF280734; HQ913712; HQ913799; HQ882749. Pitcairnia wendlandii Baker; MSBG 19960529A; AF539976.1; HQ895758; HQ913882; JF280735; HQ913713; HQ913800; HQ882750.

Puyoideae

Puya aequatorialis André; SEL 93-211; AF162260.2; L75903; HQ913884; JF280737; HQ913715; HQ913802; HQ882752. Puya alpestris (Poepp.) Gay; R. S. Jabaily 177, WIS; -; HQ895760; JF280754; JF280764; -; JF280758; JF29926; R. Horres 060, FR; AY949998; -; -; -; -; -; -. Puya castellanosii L.B.Sm.; R. S. Jabaily 149, WIS; FJ968190; HQ895761; JF280755; -; JF280762; JF280759; JF299261. Puya chilensis Molina; $R$. S. Jabaily 164, WIS; HQ900686; -; -; -; -; -; -; T. Givnish s.n., WIS; -; HQ895762; HQ913885; JF280738; HQ913716; HQ913803; HQ882753. Puya laxa L.B.Sm.; Crayn et al., 2004; AF162262; -; -; -; -; -; -; R. Horres 006, FRP; -; HQ895763; HQ913886; JF280739; HQ913717; HQ913804; AF188794/DQ084563. Puya mima L.B.Sm. \& Read; $R$. S. Jabaily 228, WIS; FJ968231; HQ895764; JF280756; JF280765; JF280763; JF280760; JF299262. Puya raimondii Harms; T. Givnish s.n., WIS; HQ900687; AY438611; HQ913887; JF280740; HQ913718; HQ913805; HQ882754. Puya venusta (Baker) Phil.; R. S. Jabaily 166, WIS; FJ968194; HQ895765; JF280757; -; -; JF280761; JF299263.

Bromelioideae

Acanthostachys strobilacea (Schult. \& Schult.f.) Klotzsch; R. Horres 019, FR; AY950021; HQ895726; HQ913823; JF280677; HQ913648; HQ913736; AF188765/DQ084606. Aechmea bromeliifolia (Rudge) Baker; $K$. Schulte 051202-4, FR; GU475466; HQ895727; HQ913824; JF280678; HQ913649; HQ913737; HQ882707. Aechmea drakeana André; G. Zizka 1100, FRP; AY950043; HQ895728; HQ913825; JF280679; HQ913650; HQ913738; AF188772/DQ084588. Aechmea haltonii H.Luther; SEL 85-1447; AF539960.2; L75844; HQ913826; JF280680; HQ913651; HQ913739; HQ882708. Aechmea lingulata (L.) Baker; Faria 81, RFA; JF295091; HQ895729; -; -; -; -; -; K. Schulte 101203-1, FR; -; -; HQ913827; JF280681; HQ913652; HQ913740; HQ882709. Aechmea nudicaulis (L.) Griseb.; K. Schulte 200603-1, FR; -; -; HQ913828; -; HQ913653; -; DQ084689/DQ084589; W. Till 18094, WU; AY614024; -; -; AY614390; -; HQ913741; -. Aechmea organensis Wawra; Wendt 342, RFA; JF295090; HQ895730; -; -; -; -; -; K. Schulte 250205-1, FR; -; -; HQ913829; JF280682; HQ913654; HQ913742; HQ882710. Aechmea racinae L.B.Sm.; Faria 80, RFA; JF295089; HQ895731; -; -; -; -; -; K. Schulte 120203-1, FR; -; -; HQ913830; JF280683; HQ913655; HQ913743; DQ084691/DQ084583. Aechmea sphaerocephala Baker; R. Horres 030b, FR; AY950045; -; HQ913842; JF280696; HQ913670; HQ913758; AF188770/DQ084578. Ananas ananassoides (Baker) L.B.Sm.; G. Brown 3129, RM; AF162227.2; L75845; HQ913831; JF280684; HQ913657; HQ913745; HQ882712. Ananas nanus (L.B.Sm.) L.B.Sm.; R. Horres \& K. Schulte 050401-9, FR; AY950054; - ; HQ913832; JF280685; HQ913658; HQ913746; DQ084695/DQ084573; SEL 1991-0469; -; HQ895733; -; -; -; -; -. Araeococcus goeldianus L.B.Sm.; Moonen s.n., SEL; -; HQ895734; -; -; -; -; -; K. Schulte 100203-1, FR; AY950002; -; HQ913833; JF280686; HQ913659;
HQ913747; DQ084630/DQ084697. Araeococcus pectinatus L.B. Sm.; SEL 85-231; AF539961.2; L75846; HQ913834; JF280687; HQ913660; HQ913748; HQ882713. Billbergia decora Poepp. \& Endl.; R. Horres 129, FR; AY950050; HQ895735; HQ913835; JF280688; HQ913661; HQ913749; DQ084698/DQ084624. Bromelia chrysantha Jacq.*; MSBG 1983-0286A; AF539962; -; JF280753; -; -; -; -. Bromelia flemingii I.Ramirez \& Carnevali*; SEL 1997-0231; -; HQ895736; -; JF280693; HQ913666; HQ913754; HQ882718. Canistropsis billbergioides (Schult. \& Schult.f.) Leme; E. Leme 171, RFA; JF295092; HQ895737; -; -; -; -; -; K. Schulte 061202-1, FR; -; -; HQ913840; JF280694; HQ913667; HQ913755; HQ882719. Canistrum aurantiacum E.Morren; E. Leme 567, RFA ; JF295094; HQ895738; -; -; -; -; -; K. Schulte 300508-4, FR; -; -; HQ913841; JF280695; HQ913668; HQ913756; HQ882720. Cryptanthus beuckeri E.Morren; SEL 89-499; AF539965.2; L75856; HQ913844; JF280698; HQ913672; HQ913760; HQ882723. Deinacanthon urbanianum (Mez) Mez; R. Horres H018, FRP; AY950017; HQ895741; HQ913845; JF280699; HQ913673; HQ913761; AF188781/DQ084607. Edmundoa perplexa (L.B.Sm.) Leme; MSBG 1987-264; AF539967.2; HQ895746; HQ913851; JF280705; HQ913679; HQ913767; HQ882727. Eduandrea selloana (Baker) Leme, W.Till, G.K.Br., J.R.Grant \& Govaerts; E. Leme 1830, HB; JF295093; L75894; -; -; -; -; -; H.B.V B00B95-1, WU; -; -; HQ913852; JF280706; HQ913680; HQ913768; HQ882743. Fascicularia bicolor (Ruiz \& Pav.) Mez; G. Zizka 1790 FRP; AY950023; -; -; -; -; -; -; D. Vandervoort s.n., WU; -; HQ895749; HQ913855; JF280709; HQ913683; HQ913771; HQ882730. Greigia sphacelata (Ruiz \& Pav.) Regel; K. Schulte 230305-4, FR; AY950015; HQ895751; HQ913858; JF280712; HQ913687; HQ913775; AF188779/ DQ084599. Hohenbergia stellata Schult. \& Schult.f.; R. Horres 037, FRP; AY950026; -; HQ913865; JF280718; HQ913694; HQ913782; AF188774/ DQ084609. Lymania alvimii (L.B.Sm. \& Read) Read; SEL 90-297; -; L75907; HQ913867; JF280720; HQ913697; HQ913784; HQ882737; $R$. Horres \& K. Schulte 050401-4, FR; AY950000;-;-;--;-;-;-. Neoregelia pineliana (Lem.) L.B.Sm.; SEL 86-261; AF539971; L75893; -; -; -; -; -; R. Horres \& K. Schulte 210601-1, FR; -; -; HQ913872; JF280725; HQ913703; HQ913790; HQ882742. Ochagavia carnea (Beer) L.B.Sm. \& Looser; R. Horres 117, FR; -; HQ895755; HQ913873; JF280726; HQ913704; HQ913791; HQ882744; R. Horres 115, FR; EU681905; -; -; -; -; -; -. Ochagavia elegans Phil.; R. Horres 23a, FR ; AY950006; HQ895756; HQ913874; JF280727; HQ913705; HQ913792; AF188778/ DQ084603. Pseudananas sagenarius (Arruda) Camargo; $M$. W. Chase 24447, K; GU475470; HQ895759; HQ913883; JF280736; HQ913714; HQ913801; HQ882751. Quesnelia quesneliana (Brongn.) L.B.Sm.; K. Schulte 300508-6, FR; -; -; HQ913888; JF280741; HQ913719; HQ913806; HQ882755; Wendt 335, RFA; JF295095; HQ895766; -; -; -; -; -. Ronnbergia petersii L.B.Sm.; SEL 78-907; -; L75897; -; -; -; -; -; K. Schulte 170203-5, FR; AY950001; -; HQ913890; JF280743; HQ913722; HQ913809; DQ084718/DQ084632. Wittrockia superba Lindm.; R. Horres \& K. Schulte 050401-8, FR; AY950025; HQ895769; HQ913899; JF280752; HQ913735; HQ913822; AF188767/DQ084611.

\section{Rapateaceae}

Rapatea paludosa Aubl.; K. J. Sytsma et al. 5157, WIS; -; AF207623; HQ913889; JF280742; HQ913721; HQ913808; HQ882764.

\section{Sparganiaceae}

Sparganium sp.; T. Givnish s.n., WIS; AB088802; AY191213; HQ913892; JF280745; HQ913724; HQ913811; HQ882765.

\section{Typhaceae}

Typha angustifolia L.*; Graham 1040, TRT; -; U79230; -; -; -; -; -. Typha latifolia L.*; T. Givnish s.n., WIS; DQ069587; -; HQ913894; JF280747; HQ913730; HQ913817; HQ882766. 